DOI:10.31142/ijahm/v9i3.02

Impact Factor: 4.415

\title{
Triterpenoid Saponins Discovery Research 2013-2016
}

\author{
Garai Saraswati \\ Organic and Medicinal Chemistry Division \\ CSIR-Indian Institute of Chemical Biology \\ 4 Raja S.C.Mullick Road, Jadavpur, Kolkata-700032 India \\ Fax No. 91-33-2473-5197/2414-9475
}

\begin{abstract}
Triterpenoid saponins isolated and characterized from various sources are reviewed. The recent techniques used in their isolation and structure elucidation are discussed. A compilation of the triterpenoid saponins isolated during the period 2013-2016 along with their occurrence, available physical data and spectroscopy used for their characterization is included. The biological activities and corrosion inhibition of the triterpenoid saponins are also discussed.
\end{abstract}

\section{Introduction}

Saponins are the plant secondary metabolites and occurs as glycosides of steroids, triterpenoids or steroidal glycosides of diverse chemical structures and various biological activities for commercial applications in the pharmaceutical, ingredients in cosmetics, fine chemicals, neutraceuticals industries, alleolochemicals in agriculture and green corrosion inhibitor in metal industry. Triterpenoid saponins are predominating constituents of this class and widely distributed throughout the plant kingdom and certain marine organisms and also marine flora and fauna. Previous review on triterpenoid saponins ${ }^{1}$ covering the literature up to 2012 recently reported. This review will focus on isolation and structure determination of novel triterpenoid saponins, new triterpenoid saponins isolated and biological activities and corrosion inhibition of these products reported during 2013-2016.

\section{Extraction and Isolation}

The isolation of triterpenoid saponins are challenging due to their occurrence as complex mixture. The recent techniques HPLC and SPE for isolation of triterpenoid saponins in complex mixture have been applied.

Ulososides and urabosides, new triterpenoid saponins from the carribbean Marine Sponge Ectyoplasia ferox were isolated. The sponge specimen was lyophilized and extracted with dichloromethane-methanol (1:1) mixture. The dried $\mathrm{CH}_{2} \mathrm{Cl}_{2}-\mathrm{MeOH}$ extract was chromatographed by $\mathrm{RP}-\mathrm{C}_{18}$ column and eluted with $\mathrm{H}_{2} \mathrm{O} / \mathrm{MeOH}$ (7:3) and $\mathrm{MeOH} / \mathrm{CH}_{2} \mathrm{Cl}_{2}$ (1:1) mixture. The methanol fraction thus obtained was further

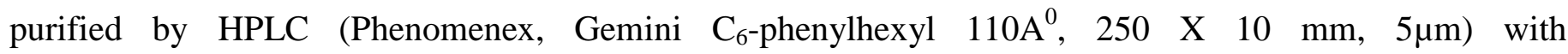
$\mathrm{H}_{2} \mathrm{O} /$ Acetonitrile/TFA (Flow rate 3.0Ml/min, 60:40:0.1-45:55:0.1) to give ulososides $\mathrm{F}$ and Urabosides A \& $\mathrm{B}^{2}$.

The aerial parts of Spergula fallax were macerated and extracted with $80 \% \mathrm{MeOH}$ under reflux. The crude saponin extract obtained was dissolved in $\mathrm{H}_{2} \mathrm{O}$ and purified by flash chromatography $\left(\mathrm{C}_{18}\right.$ column $6 \times 10 \mathrm{~cm}$,

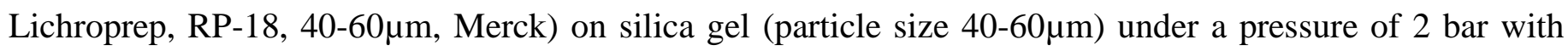
$\mathrm{H}_{2} \mathrm{O}, \mathrm{MeOH} / \mathrm{H}_{2} \mathrm{O}, 20 \%, 40 \%, 60 \%, 80 \%$ and $\mathrm{MeOH}$ respectively. The fractions thus obtained were further purified by HPLC on $\mathrm{C}_{18} \mu$ Bondapack column to yield four glycosides ${ }^{3}$. 
Garai Saraswati , International Journal of Ayurvedic \& Herbal Medicine 9(3) May.-June. 2019 (3492-3513)

\section{Structure Elucidation}

The structure elucidation of pure saponins were generally investigated by a combination of chemical and spectroscopic methods. The newer spectroscopic techniques has been applied for complete structure determination of small amount of the intact saponin.

\subsection{NMR spectrometry}

The structures of four glycosides with novel aglycones isolated from Spergula fallex were determined by ${ }^{1} \mathrm{H}$, ${ }^{13} \mathrm{C}$, TOCSY and 2D NMR (DQF-COSY, HSQC, HMBC and ROESY experiments).

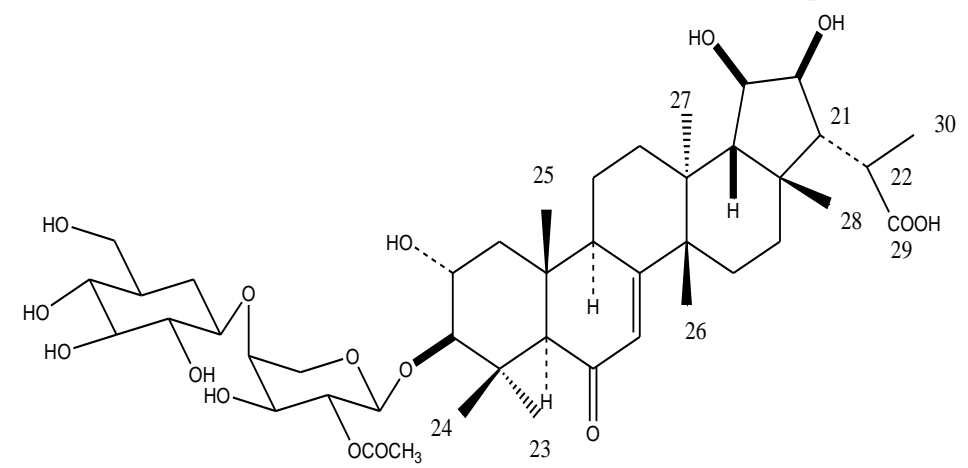

\section{Compound 1}

The COSY correlation between $\mathrm{H}-3 / \mathrm{H}-2$ was observed indicating the presence of two hydroxyl groups at C2 and $\mathrm{C}-3$ and also their configurations as $\alpha$ and $\beta$ respectively by the coupling constant $\mathrm{H}-3$ and by the ROESY correlations between $\mathrm{H}-2 / \mathrm{Me}-25$ and $\mathrm{H}-3 / \mathrm{H}-5 / \mathrm{Me}-23$. The HMBC correlations between $\mathrm{H}-7 / \mathrm{C}-5$ and C-7/C-6 were observed suggesting the presence of double bond at C-7 and the carbonyl group at C-6 of the aglycone moiety. The ROESY spectrum correlations was observed between H-9/M-27 and H-18/Me26/H-21. The ROESY correlations were not observed between $\mathrm{H}-9 / \mathrm{Me}-25, \mathrm{Me}-28 / \mathrm{H}-18 / \mathrm{H}-21$. Thus compound 1 is a fernane-type triterpenoid. The long range correlation between $\mathrm{Me}-30 / \mathrm{H} 21$ revealed that one of the methyl groups of the isopropyl function connected by a carboxylic group. ${ }^{1} \mathrm{H} \&{ }^{13} \mathrm{C}$ NMR indicated the presence of one arabinose and one glucose units. The linkage site of the two sugars arabinose and glucose were confirmed by HMBC spectrum. The configurations of the arabinose and glucose units were established from ${ }^{2} \mathrm{~J}_{\mathrm{H}-1, \mathrm{H}-2}$ which were found to be $5.2 \mathrm{~Hz}$ and $8.0 \mathrm{~Hz}^{3}$.

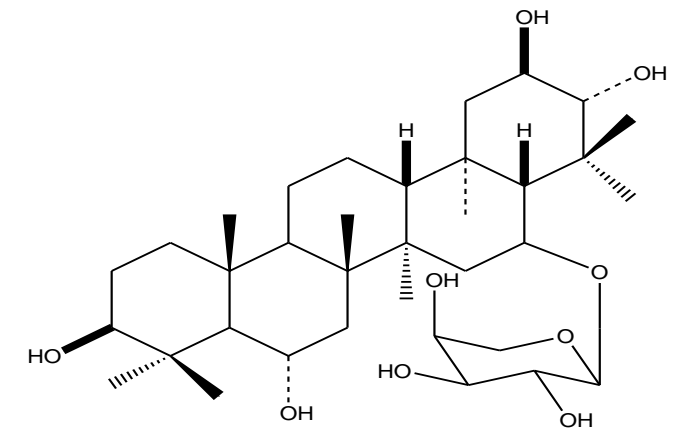

Compound 2 (2)

The structure of a new triterpenoid glycoside, compound $\mathbf{2}$ with new aglycone was determined. The ${ }^{1} \mathrm{H} \&$ ${ }^{13} \mathrm{C}$, HSQC, HMBC and ROESY spectra identified the hydroxylated derivative of tetrahymanol type skeleton of the aglycone moiety attached with one sugar. It showed eight methyl groups, seven methine carbons and and one anomeric signal. The attachment of the arabinose unit to the C-16 of the aglycone was confirmed by HSQC and HMBC correlations. The L configurations of the arabinose unit was established by GC analysis ${ }^{3}$.

\subsection{Mass spectrometry}

The molecular masses of saponins are conveniently determined by Fast atom mass spectrometry (FABMS) and electrospray ionization mass spectrometry (ESIMS) in the positive and / or negative mode. 
Garai Saraswati , International Journal of Ayurvedic \& Herbal Medicine 9(3) May.-June. 2019 (3492-3513)

The molecular ion peak at $m / z 877[\mathrm{M}+\mathrm{Na}]^{+}$and other fragments ions at $m / z 835[\mathrm{M}+\mathrm{Na}-42]^{+}, m / z 673$ $[\mathrm{M}+\mathrm{Na}-42-162]^{+}$and $m / z 541[\mathrm{M}+\mathrm{Na}-42-162-132]$ were obtained in positive ESIMS for the monodesmoside fernane saponin [3]. In the ESIMS/MS spectrum the $[\mathrm{M}+\mathrm{H}]^{+}$ion at $m / z, 881$ of oleanane saponin provided fragments by loss of two units at $\mathrm{m} / \mathrm{z}, 705$ and $\mathrm{m} / \mathrm{z} 529$ indicating the presence of two glucuronic acid or galactouronic acid in the glycone moiety ${ }^{4}$.

\section{Biological activities}

\subsection{Antimicrobial activity}

Triterpenoid saponins exhibit divergent antimicrobial activities. Saponins are generally good antifungal and antibacterial agent. The antifungal activity is found to be more effective with saponins than the sapogenins and the acetylated saponins, the activity being highly influenced by the number of component monosaccharides and their sequence.

Antibacterial activity of the methanolic extract containing saponins of the leaves of Pavetta indica was investigated against Bacillus subtilus, Escherichia coli and Saccharomyces cerevisiae using disc diffusion assay. The antimicrobial studies was performed using $250 \mathrm{mg} / \mathrm{ml}$ of the crude extract in DMSO and serially diluted (1:1) with media to concentrations of 125, 62.5, 31.3, 15.6, 7.8, 3.9, 1.95 and $0.98 \mathrm{mg} / \mathrm{ml}$. It showed bactericidal activity against Bacillus subtilus (Table 1). Minimum inhibitory concentration (MIC) and Minimum bactericidal concentration (MBC) were found to be between $1.95-7.89 \mathrm{mg} / \mathrm{mL}$ after incubation at $30^{\circ} \mathrm{C}$ for $18-24 \mathrm{hrs}$. The inhibition zones formed around the discs was measured. Ampicillin $(250 \mu \mathrm{g} / \mathrm{ml})$ and commercial Fluconazole $(10 \mathrm{mg} / \mathrm{ml})$ were used as positive controls (Table 2). The leaf extracts in $1.5 \mathrm{ml}$ microfuge tubes at a $250 \mathrm{mg} / \mathrm{ml}$ concentration in DMSO were treated at $40^{\circ}, 60^{\circ}, 80^{\circ}$ and $100^{\circ} \mathrm{C}$ and autoclaved at $15 \mathrm{psi}$ for $15 \mathrm{~min}$ separately to determine the effect of temperature on the stability. The samples were cooled to room temperature and the residual antibacterial activities were determined against the bacteria by disc diffusion method. The isolated constituents of Pavetta indica may have application as preservative in food processing industry to inhibit the microbial growth in processed food products and human health care ${ }^{5}$.

The antimicrobial effect of Silene vulgaris extract was studied by using broth microdilution assay for determination of minimum inhibitory concentrations in attempt to evaluate its preservative efficacy. S.vulgaris extract was found to be active against Gram-negative bacteria Pseudomonas aeruginosa and the yeast Candida albicans at the concentrations $3 \mathrm{mg} / \mathrm{ml}$ and $6 \mathrm{mg} / \mathrm{ml}$ whereas the extract was less active against Escherichia coli ATCC2522 and Staphylococcus aureus ATCC29213 and Aspergilus brassiliensis ATCC16404 (Table 3). The microbial challenges test results performed by the European Pharmacopocia using the tested strains demonstrated that S.vulgaris extract at $10 \%$ and $20 \%$ (w/w) reduced the bacteria and fungi inocula with a significant conservation during a period of 28 days compared to synthetic preservative, phenoxyethanol. The silene extract could be considered as an natural preservative for cosmetic formulation ${ }^{6}$. The in-vitro fungicide activity of hydroalcoholic extract of saponin mixture from Sapindus saponaria against 125 vaginal yeasts including Candida and Saccharomyces genus was evaluated by broth microdilution method. A time-kill assay was performed to determine the growth profile curves for C.albicans ATCC90028 in YPD broth that was exposed to $1560 \mu \mathrm{g} / \mathrm{ml} \mathrm{HE}$ (i.e the highest MIC value found) for 240 min (Figure 1). A substantial reduction of colony forming units (CFU) was observed compared with the control groups fluconazole and Nystatin indicating the fungicide activity of HE in the first $60 \mathrm{~min}$ of exposure. General morphological changes in Candida albicans ATCC90028 cells using SEM and TEM. Hydroalcoholic extract of S.saponaria was further studied. It suggests that saponins bind components of the cytoplasmic membrane in yeast cells and cause celllysis which occurred within minutes after contact ( Figure 2A). After $30 \mathrm{~min}$ a sharp drop in CFU which persisted up to $120 \mathrm{~min}$ and reached a plateau unit until 240 min (Figure 2B) was observed. A significant reduction of the amount of yeast was observed after 
Garai Saraswati , International Journal of Ayurvedic \& Herbal Medicine 9(3) May.-June. 2019 (3492-3513) 30 min exposure to HE. Figure 3B show rupture of the cell wall indicating celllysis. The interaction between saponins and the membrane constituents of yeast cells caused the loss of intracellular contents and cell wall disorganization causing the presence of irregularities in the cell wall (Figure 3C) and consequently cell death ${ }^{7}$.

The antibacterial activity of the methanol extract containing saponins of Gymnema sylvestre was investigated by agar well diffusion method against four Gram-negative (Escherichia coli, Klebsialla pneumonia, Pseudomonas aerruginosa, Proteus vulgaris) and five Gram-positive bacteria (Bacillus subtilus, Enterococcus faicalis, Microcococcum luteus, Staphylococcus aureus, Steptococcus pseumeniae). Methanol extract exhibited higher inhibition zones against all the tested bacteria. The low MIC values of methanol extract were $15.6 \mu \mathrm{g} / \mathrm{ml}$ against B.subtilis, S.aureus, $31.2 \mu \mathrm{g} / \mathrm{ml}$ against E.facelis, M.luteus, S.pneumoniae. G.sylvestre may possess promising therapeutic action in the treatment of infectious diseases caused by the species like E.coli and S.aureus. The antimicrobial potential is due to the lytic action of the extracts causing cell death. The methanolic extract reacts with peptidoglycan layer of the outer lipolysaccharide layer to form protease inhibitors of the gram negative strains by damaging its cell membrane. Further studies needed to identification of saponins responsible for antibacterial activity ${ }^{8}$.

The highest antifungal activity was observed in methanolic extract of Bacopa monniera at 10mg/ml, $5 \mathrm{mg} / \mathrm{ml}, 2.5 \mathrm{mg} / \mathrm{ml}$ and $1.25 \mathrm{mg} / \mathrm{ml}$ concentrations, and maximum zone of inhibition was observed against Aspergilus niger and Candida albicans at $2.5 \mathrm{mg} / \mathrm{ml}$ and $1.25 \mathrm{mg} / \mathrm{ml}$ concentration where as in aqueous extract no antifungal activity was observed by the agar well diffusion method.. No antibacterial activity was observed against S.aureus, B.subtilis, E.coli, Pseudomonas aeruginosa in aqueous and methanolic extracts of B.monniera (L.) ${ }^{9}$. The antimicrobial activity studies of the ethanolic and water extract of the garlic (Allium sativum) by the agar well diffusion method against the test organisms Staphylococcus aureus, Salmonella typhimurium and Pseudomonas aeruginosa in comparison with gentamycin and chloromphenicolas positive controls showed that both the extract have higher inhibitory activity. Inhibitory test was carried by $1.5 \mathrm{ml}$ of the test organism from the $48 \mathrm{~h}$-old culture of the ethanol and water extract. $20 \mathrm{ml}$ of sterile media was aseptically poured in each dish. A clear zone around the disc of the ethanol and water extract after incubation at $37^{\circ} \mathrm{C}$ for $24 \mathrm{hrs}$ indicative of inhibition was observed. The garlic extract may be used in foods and pharmaceutical products ${ }^{10}$.

The invitro antimicrobial activity of methanolic fractions obtained from rhizome of Curcuma longa was investigated against standard strain and clinical isolated from Staphylococcus aureus. The antibacterial spectra showing zone of inhibition in millimeters and calculated as percentage by taking gentamycin as positive control with $100 \%$ inhibition. Scanning electron microscopic observations revealed that test pathogen treated with methanolic extracts showed morphological deformity with partial lack of the cytoplasmic membrane which leads to cell disruption. The ability of rhizome of C.longa methanolic extracts to inhibit the growth of test pathogen is an indication of its broad spectrum antimicrobial potential which may be employed in the management of microbial infection. The methanolic fraction of C.longa rhizome showed high potential to inhibit some pathogenic bacteria of Staphylococcus aureus ${ }^{11}$.

\subsection{Antitumor/Anticancer and Antioxidant activities}

Jujuboside B isolated from the seeds of Zizyphus jujuba used as a traditional medicine for the treatment of insomnia and anxiety was investigated for the studies of antitumor mechanism in vivo and in vitro of AGS and HCT 116 human cancer cells in a tumor xenograft model. Cell viability was observed with $\mathrm{IC}_{50}$ values of 107 and $114 \mu \mathrm{M}$ in AGS human gastric cancer cells and HCT 116 human colon cancer cells. The $\mathrm{IC}_{50}$ value of $182 \mu \mathrm{M}$ in chang hepatic normal cells indicated a more potent cytotoxicity effect of Jujuboside B against cancer cells ( Figure 4A, 4B, 4C, 4D). The annexin V positive apoptotic cell population increase in AGS cells and the sub $\mathrm{G}_{1}$ phase increase in HCT 116 cells indicated apoptotic cell death (Figure 5C, 15D). Jujuboside B inhibited tumor growth $60 \%$ compared with the control group (Figure 15A) and reduced the 
Garai Saraswati , International Journal of Ayurvedic \& Herbal Medicine 9(3) May.-June. 2019 (3492-3513) expression of the proliferation biomarker $\mathrm{K}_{\mathrm{i}}-67$ in the tumor tissues (Figure 5C). No toxicity and body weight change in each mouse were observed (Figure 5B).

Jujuboside B induced extrinsic pathway-mediated apoptosis through Caspase- 8 activation and the increase in FasL and Caspase 3 activation and PARP-L cleavage detection (Figure 6A, 6B, 6C). The autophagy inhibitor bafilomycin $A_{1}\left(B_{a} F\right)$ decreased jujuboside-induced-cell-viability and increased pp38, pJNK, FasL, caspase-8-activation and caspase-3-activation. These results demonstrated jujuboside B induced protective autophagy to retard extrinsic pathway-mediated apoptosis and indicated by the formation of cytoplasmic vacuoles and microtubule-associated protein 1 light chain-3I (LC3-I) (Figure 7, Figure 7A, 7B, 7C) $)^{12}$.

Cytotoxicity evaluation of crude extract and total saponin fraction of Chlorophytum borivilianum against MCF-7 and HCT-116 cancer cell lines using MTT cell viability assay indicated a higher cytotoxicity activity of the crude extract than the total saponin fraction on all cell lines being most effective and selective on MCF-7 human breast cancer cell line. Total saponin has higher $\mathrm{IC}_{50}$ than crude extract indicating highly quenching capacity of crude extract (Table 4) ${ }^{13}$.

The effects of $100 \mu \mathrm{g} / \mathrm{ml}$ of both water and ethanol extracts on pancreatic cancer cells derived from both water and ethanol extracts of Papaya carica on pancreatic cancer cells derived from both primary (MiaPaCa-2) and metastatic (ASPC-1) sites was assessed with control gemcitabine ${ }^{14}$.

Human pancreatic cancer cells (MiaPaCa-2 and ASPC-1) were cultured at $37^{\circ} \mathrm{C}, 5 \% \mathrm{CO}_{2}$, Dulbecco's Modified Eagle's Medium (DMEM) supplemented with 10\% foetal bovine serum (FBS), horse serum and L-glutamine $(100 \mu \mathrm{g} / \mathrm{mL})$ was used for MiaPaCa-2, while 10\% FBS in RPM1 media was used for ASPC-1. Cell viability was determined using the Dojindo Cell Counting Kit-8. Cells were seeded into a 96 well plate at $5 \times 10^{3}$ cells per well and allowed to adhere for $24 \mathrm{~h}$. The cells were then treated with $100 \mu \mathrm{g} \mathrm{mL}^{-1}$ of crude papaya ethanolic extract, crude papaya water extract or gemcitabine $\left(\mathrm{IC}_{50}-50 \mathrm{nM}\right)$. After $72 \mathrm{~h}, 10 \mu \mathrm{L}$ of CCK-8 solution was added before incubating at $37^{\circ} \mathrm{C}$ for $90 \mathrm{~min}$. The absorbance was recorded (450nm), and cell viability was determined as a percentage of control. The ethanol extract decreased cell viability of MiaPaCa-2 and ASPC-1 pancreatic cancer cells by $81 \%$ and $54 \%$ at $100 \mu \mathrm{g} / \mathrm{ml}$. Ethanol extracts were more effective in inhibiting the proliferation of two pancreatic cells MiaPaCa-2 ( $\mathrm{P}=0.09)$ and ASPC-1 cells $(\mathrm{P}=0.04)$ (Table 5) and were at least as effective as the chemotherapeutic agent

The rate of discoloration by extracts or antioxidant compounds indicates the potential of their scavenging in terms of hydrogen donating ability. The lowest absorbance at $517 \mathrm{~nm}$ of reaction between DPPH and serial dilution of crude and total saponin extracts of mother plant tubers of C.borivilianum indicated higher free radical scavenging activity. Total saponin has higher $\mathrm{IC}_{50}$ than crude extract indicating highly quenching capacity of crude extract. The inhibition of peroxidation of macromolecules by extracts of mother plant tubers of $C$.borivilianum was investigated by ferrous ions $\left(\mathrm{Fe}^{2+}\right)$ chelating activity. The chelating abilities of the crude and total saponin extracts were $2.4 \%$ and $36.5 \%$ at $0.5 \mathrm{mg} \mathrm{mL}^{-1}$ and $30 \%$ and $72.2 \%$ at $2.5 \mathrm{mg} \mathrm{mL}^{-}$ ${ }^{1}$, respectively. Total saponin in all concentrations $\left(0.5,1,1.5\right.$ and $\left.2.5 \mathrm{mg} \mathrm{mL}^{-1}\right)$ showed high FIC values $(\mathrm{p}<0.05)$ indicating higher antioxidant activity. In this study $\mathrm{FC}_{50}$ value of total saponin was $1 \mathrm{mg} \mathrm{mL}^{-1}$ but crude extract showed $>2.5 \mathrm{mg} / \mathrm{mL}$.

The antioxidant activity of crude and total saponin extracts of C.borivilianum was also evaluated by the BCB assay. In this study the crude extract displayed stronger inhibition effect $(80.6 \pm 0,8 \%)$ at $2 \mathrm{mg}$ compared to total saponin which showed $61 \pm 1.14 \%$ at the same quantity. $\mathrm{IC}_{50}$ of the crude and total saponin extracts showed 0.7 and $1.3 \mathrm{mg} / \mathrm{mL}$ indicating higher antioxidant activity of crude extract ${ }^{13}$.

The ethanol extract of Papaya carica used as folk medicine showed higher antioxidant capacity than the water extract above $100 \mu \mathrm{g} / \mathrm{ml}$ concentrations compared to the one-fifth of tocopherol using SSA and ABTS assay. The ethanol and water extract at concentrations $200 \mu \mathrm{g} / \mathrm{ml}$ showed higher free radical scavenging capacity (Table 6) ${ }^{14}$. 
Garai Saraswati , International Journal of Ayurvedic \& Herbal Medicine 9(3) May.-June. 2019 (3492-3513)

The antioxidant activities of the isolated saponin was assessed on the basis of the radical scavenging effect of $\mathrm{DPPH}$ from the leaves of Tridox procumbens. The $\mathrm{IC}_{50}$ value of saponin fractions was found to be $0.13 \mathrm{mg} / \mathrm{ml}$. It showed moderate to good antioxidant activity ${ }^{15}$.

The antioxidant activities of saponin extracted from the root of Garcinia kola was studied in terms of the free radical theory of oxidation. The saponin extract at the dose of 100,200 and $400 \mathrm{mg} / \mathrm{kg}$ body weight daily for 7 days given to the hyperglycemic rats treated with $200 \mathrm{mg} / \mathrm{kg}$ of control metformin. The in vivo antioxidant assay results showed that saponin at different concentrations significantly decrease the MDA level compared to metformin and the control group $(\mathrm{p}<0.05)$, the activities of antioxidant enzymes, superoxide dismutase (SOD) and catalase of albino rats given saponin increases compared with the control group. The in vitro antioxidant assay results suggest that the saponin extract has effective radical scavenging activity against DPPH, ferric induced, hydrogen peroxide, hydroxyl, nitric oxide, superoxide radicals in a dose dependent manner. The saponin extract have significant antioxidant and free radical scavenging activities and could be a potential source of natural antioxidant for antiaging factor ${ }^{16}$.

The n-butanol extract of Radix trichosanthis has lowest $\mathrm{IC}_{50}$ compared with the EtOAc indicating the potential antioxidant reagent in vitro. The EtOAc extract and n-butanol extract have higher scavenging ability than that of control group in a time dependent manner. In vivo assay, an increase of SOD and T-AOC and decrease of MDA and LDH levels were only observed in n-butanol $(2 \mathrm{mg} / \mathrm{kg} / \mathrm{d}$ of crude drug) extracts pretreatment group. An increase in MDA and decrease in SOD and T-AOC levels was observed in EtOAc extracts. $n$-butanol fraction has the antioxidant potency both in vitro and in vivo ${ }^{17}$.

\section{Green Corrosion Inhibition}

Achyranthes aspera (AA) extracts were studied as corrosion inhibitor for mild steel (MS) in industrial water medium using gravimetric and electrochemical measurements. The inhibition efficiency was determined by hanging the steel coupon measuring $1.0 \times 1.0 \times 0.1 \mathrm{~cm}^{3}$ into the solution $\left(100 \mathrm{~cm}^{3}\right)$ containing the extract solution at $30^{\circ}-60^{\circ} \mathrm{C}$ for 10 to $50 \mathrm{~h}$. The electrochemical experiments were performed using a $\mathrm{CH}$-analyzer model CH1660D. Saturated calomel electrode, platinum counter electrode and mild steel as working electrode were used respectively as reference auxiliary electrode. Electrochemical impedence spectroscopy (EIS) studies were performed by the potential range from -350 to $-800 \mathrm{mV}$ with a scan rate of $0.4 \mathrm{mV}_{\mathrm{s}}^{-1}$ and in the frequency range from $10 \mathrm{KHz}$ to $0.05 \mathrm{~Hz}$ with signal amplitude of $\pm 10 \mathrm{mV}$. The surface morphology of the mild steel samples in the absence and presence of AA methanolic extracts (1200ppm in industrial water) at $30^{\circ} \mathrm{C}$ was investigated by scanning electron microscopy (SEM) technique ${ }^{18}$.

The inhibition efficiency of AA extracts increases with the inhibitor concentration and reaches a maximum at $1200 \mathrm{ppm}$ of AA extracts. IE\% decreases with the increasing temperature in industrial water medium and remains constant at higher temperature. The adsorption of AA extracts in industrial water medium on MS surface obeys Langmuir adsorption isotherm. The adsorption process involved is both physorption and chemisorptions. Polarization curves indicated that AA extracts acted as mixed type of inhibitor.

The Polisota hirsute extract was found to be effective green inhibitor of aluminium alloys corrosion in $0.25 \mathrm{M} \mathrm{KOH}$ environment at $303 \mathrm{~K}$. The extract inhibited the corrosion of aluminium alloys media by means of hindering both cathodic and anodic electrode processes because the greater the number of bonds in the extracts, the higher the inhibition efficiency. The inhibitive action was basically controlled by the concentration of the inhibiting extract in the medium. The inhibitor obeys both the Langmuir adsorption isotherm and the Temkin isotherm in the medium ${ }^{19}$.

Thymus Vulgarize extract (TVE) was reported to be good corrosion inhibitor for copper and brass in acid media. Experimental study was investigated the efficiency of Thyme leaves extract as corrosion inhibitor for concrete reinforcing steel samples exposed to alkaline solution consisting of $2 \% \mathrm{KOH}$ and $3 \% \mathrm{NaCl}$ which is a simulation to the chloride contaminated concrete pore solution (SCP) using open circuit potential and 
Garai Saraswati , International Journal of Ayurvedic \& Herbal Medicine 9(3) May.-June. 2019 (3492-3513) potentiodynamic polarization technique. Various concentration $(100 \mathrm{ml} / \mathrm{L}, 150 \mathrm{ml} / \mathrm{L}, 250 \mathrm{ml} / \mathrm{L})$ of TVE were used in this experiment ${ }^{20}$.

The anticorrosion behaviours of agarwood leaves extracts in $1 \mathrm{M} \mathrm{HCl}$ solution on mild steel were studied using weight loss, potentiodynamic measurement, electrochemical impedance spectroscopy and scanning electrol microscopy techniques. The extracts showed good inhibition efficiencies for the gravimetric electrochemical methods. EIS analysis revealed that inhibition efficiency increases proportionately with the concentration and the charge transfer resistance. The potentiodynamic polarisation measurements showed the extracts acted as mixed-type inhibitors with predominantly cathodic effectiveness. SEM techniques supported the success of corrosion inhibition with the presence of inhibitors and the methanol extract best fitted the Temkin adsorption isotherm while the aqueous extract best fitted the Langmuir and Temkin adsorption isotherms. The adsorption mechanisms for both extracts were mainly physisorption ${ }^{21}$.

Emila sonchifolia extracts were investigated as green corrosion inhibitor of mild steel in $1.0 \mathrm{M} \mathrm{H}_{2} \mathrm{SO}_{4}$ by weight loss method. This method showed that inhibition efficiency increased with an increase in ES extract concentration, but decreased with rise in temperature. Adsorption on mild steel was found to obey Langmuir adsorption isotherm and kinetic thermodynamic model of EI-Anady et al from the fit of experimental data. The presence of ES increased the corrosion activation energy. The free energy and heat of adsorption gave negative values. The values obtained support the physical adsorption mechanism ${ }^{22}$.

Corrsion inhibitors from natural products have been considered preferential due to the environment friendly effect. Black tea extract containing triterpenoid saponins was tested as corrosion inhibitors for carbon steel in $1 \mathrm{M} \mathrm{HCl}$ solution using electrochemical frequency modulation (EFM), Potentiodynamic polarization and electrochemical impedance spectroscopy (EIS) techniques.

Potentiodynamic polarization measurement indicated that black tea acted as a mixed type inhibitors. The adsorption of the extract on carbon steel is found to obey Temkin adsorption isotherm. SEM study confirmed the adsorption of the extract molecules on the carbon steel surface ${ }^{23}$.

\section{Conclusions}

The clarification of structure-activity relationships on the basis of medicinal importance, agriculture, commercial value and potential for further research and development has been increasing among the novel and potential bioactive triterpenoid saponins. The recent trend has been for use of herbal and marine drugs or medicines among the people due to its low cost, natural abundance and least side effects. The applications of triterpenoid saponins in food processing industry and cosmetics have been increasing in recent years to explore alternative sources of safe, effective and acceptable natural preservatives. The study of saponins has by now provided enough material for scientists to extract structural information that can be used to make designed compounds. The study of corrosion inhibition of crude extract of plant saponins in metal industry has been developed as low cost and less environmental impact.

\section{Reports of New Triterpenoid Saponins during 2013-2016}

New triterpenoid saponins isolated during the period 2013-2016 together with their natural distribution, available physical data

and various spectra recorded for their characterization and listed in Table 7. The structures 3-38 are of the aglycones of various saponins listed.

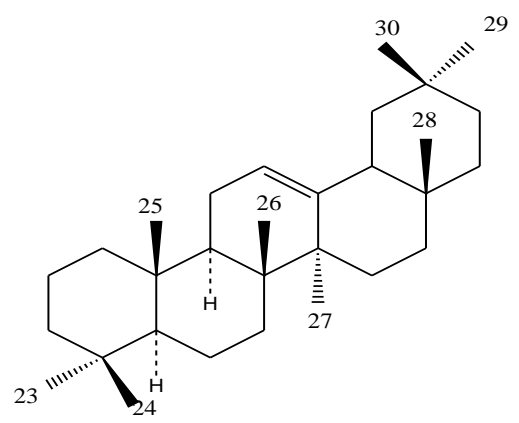


(3) $\mathrm{HO}-3 \beta, 16 \alpha, 21 \alpha, \mathrm{CO}_{2} \mathrm{H}-28$, acacic acid

(4) $\mathrm{HO}-3 \beta, 16 \alpha, \mathrm{CO}_{2} \mathrm{H}-28$, echinocystic acid

(5) $\mathrm{HO}-3 \beta, 23, \mathrm{CO}_{2} \mathrm{H}-28$, hederagenin

(6) $\mathrm{HO}-3 \beta, 16 \alpha, \mathrm{CHO}-23, \mathrm{CO}_{2} \mathrm{H}-28$, gypsogenin

(7) $\mathrm{HO}-3 \beta, 22 \beta, 24,29$

(8) $\mathrm{HO}-3 \beta, 22 \beta, 24, \mathrm{CO}_{2} \mathrm{H}-29$

(9) $\mathrm{HO}-3 \beta, 21 \beta, 22 \alpha, 24$

(10) $\quad \mathrm{HO}-3 \beta, 22 \beta, 24$

(11) $\quad \mathrm{HO}-3 \beta, 24$, oxo-22, $\mathrm{CO}_{2} \mathrm{H}-29$

(12) HO-3 $\beta, 21 \beta, 22 \alpha, 24,29$

(13) $\quad \mathrm{HO}-3 \beta, \mathrm{CO}_{2} \mathrm{H}-28,15: 16-\mathrm{ene}$

(14) $\mathrm{HO}-3 \beta, \mathrm{OAc}-22 \beta$, oxo- $11, \mathrm{CO}_{2} \mathrm{H}-30$

(15) HO-3 $\beta, 24$, oxo- $11, \mathrm{CO}_{2} \mathrm{H}-30$

(16) $\mathrm{HO}-3 \beta, 24$, oxo-11, $\mathrm{CO}_{2} \mathrm{H}-29$

(17) HO-3 $\beta$, oxo-11, CHO-30

(18) HO-3 $\beta$, oxo- $11,22 \beta \rightarrow 30$ lactone

(19) $\mathrm{HO}-3 \beta, 21 \alpha$, oxo-11, $\mathrm{CO}_{2} \mathrm{H}-30$

(20) HO-3 $\beta, 22 \beta$, oxo-11

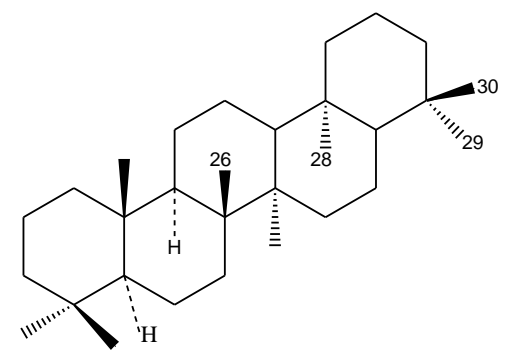

(21) HO-3 $\beta, 6 \alpha, 16 \alpha, 20 \beta, 21 \alpha$

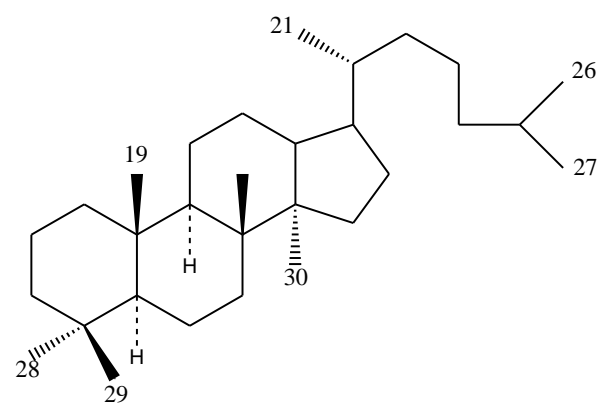

(22) HO-3 $\beta, 6 \alpha, 20(\mathrm{~S})$, oxo-12, 24:25-ene

(23) HO-2 $\alpha, 11 \alpha, 20(\mathrm{R}), 25$, OAc-3 $\alpha$

(24) HO-2 $\alpha, 11 \alpha, 25$, OAc-3 $\alpha, 20: 21$-ene

(25) HO-2 $\alpha, 11 \alpha, 20(\mathrm{~S})$, OAc-3 $\alpha, 24: 25$-ene

(26) HO-2 $\alpha, 11 \alpha, 20(\mathrm{R}), 25, \mathrm{OAc}-3 \alpha, 24: 25$-ene

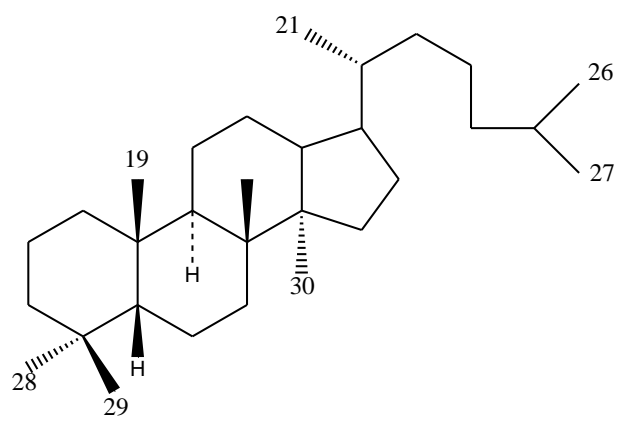


Garai Saraswati , International Journal of Ayurvedic \& Herbal Medicine 9(3) May.-June. 2019 (3492-3513) HO-3 $\beta, 28$, oxo-23, $\mathrm{CO}_{2} \mathrm{H}-29,8: 9$-ene

(28) HO-3 $\beta$, oxo-23, $\mathrm{CO}_{2} \mathrm{H}-28,29,8: 9$-ene

(29) $\mathrm{HO}-3 \beta, 22(\mathrm{R}), 23(\mathrm{~S}), \mathrm{CO}_{2} \mathrm{H}-29,8$ :9-ene

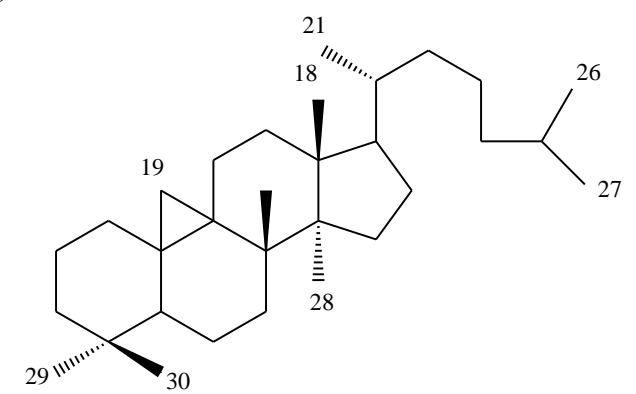

(30) HO-3 $3,10(\mathrm{~S}), 24(\mathrm{R}), 25$, oxo-16, 23, 9, 10 seco, 7:8, 9:11-ene

(31) HO-3 $\beta, 10(\mathrm{R}), 24(\mathrm{R}), 25$, oxo-16, 23, 9, 10 seco, 7:8, 9:11-ene

(32) HO-3 $\beta, 10(\mathrm{~S})$, oxo-16, 23, 23:24(R)-epoxy, 7:8, 9:11-ene

(33) HO-3 $\beta, 11 \beta, 23 \alpha$, oxo-16, 23, 9, 10 seco, 7:8, 24:25-ene

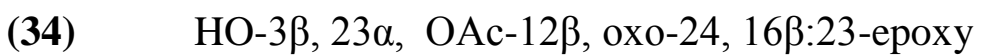

(35) HO-3 $\beta, 24 £, 25$, OAc-12 $\beta, 16 \beta$ :23-epoxy, 22:23-ene

(36) HO-3 $\beta, 23(\mathrm{~S}), 24(\mathrm{~S})$, OAc-12 $\beta, 16 \beta: 23,22: 25$-ероху

(37) HO-3 $\beta, 10(\mathrm{R})$, oxo-16, 23, 23:24-epoxy, 7:8, 8:9-ene

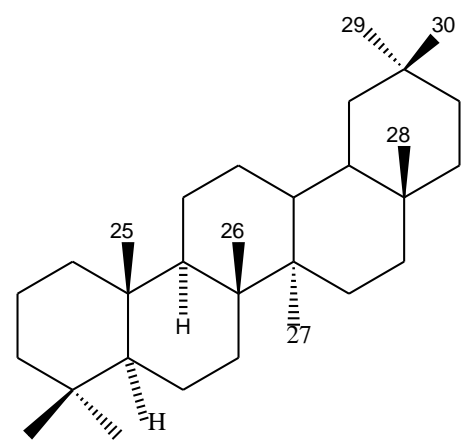

(38)

$\mathrm{OH}-3 \beta, \mathrm{CO}_{2} \mathrm{H}-29,11: 12,13: 18$-ene

\section{Acknowledgement}

Financial support from CSIR, New Delhi is gratefully acknowledged.

\section{Conflict of Interest}

Financial support from CSIR, New Delhi.

\section{References}

1. Garai, S. Advances in Triterpenoid Saponins Research 2007-2012. J.Herbal Medicine 2016; 2(3): 123.

2. Colorado J, Munoz D, Marquez D, Elena Marquez M, Lopez J. Thomas OP, Martinez A et al. Ulososides and Urabosides-Triterpenoid Saponins from the Caribbean Marine Sponge Ectyoplasia ferox. Molecules 2013; 18: 2598-2610, doi 10.3390/molecules 18032598.

3. Hamed AI, Masullo M, Pecia L, Gallotta D, Mahalel VA, Pawelec S, Stochmal A, Piacente S et al. Unusual Fernane and Gammacerane Glycosides from the Aerial Parts of spergula fallex. J. Nat. prod 2014; 77: 657-682.

4. Song, W., Si, L., Ji, S., Wang, H., Fang, XM., Yu, LY., Li, RY., Liang, LN., Zhou, D., Ye, M et al. Uralsaponins M-Y, Antiviral Triterpenoid Saponins from the Roots of Glycyrrhiza uralensis. J.Nat.Prod. 2014; 77: 1632-1643. 
Garai Saraswati , International Journal of Ayurvedic \& Herbal Medicine 9(3) May.-June. 2019 (3492-3513)

5. Gupta VK, Kaur C, Simlai A, Roy A. Antimicrobial activity of Pavetta indica leaves. J.Appl.Pharm.Sci.2013; 3(): 78-82.

6. Boukhira S, Balouiri M, Mansouri LE, Youbi AEHE, Bouarfa M, Lebtar S, Ouhammou A, Bousta D et al. J. Appl.Pharm.Sci 2017; 7(): 142-148.

7. Shinobu-Mesquita CS, Bonfim-Mendonca PS, Moreira AL, Ferreira ICP, Donatti L, Fiorini A, Svidzinski TIE et al. Cellular Structural changes in Candida albicans caused by the Hydroalcoholic Extract from Sapindus saponaria L. Molecules 2015; 20(): 9405-9418 doi: 10.3390/molecules 20099405.

8. Naidu GK, Naidu KCS, Sujatha B. In Vitro Antibacterial Activity and Phytochemical Analysis of Leaves of Gymnema sylvestre Retz. R.Br. Int.J.Pharm Tech Res 2013; 5: 1315-1320.

9. Pawer SS, Jadhav MG, Deokar TG. Study of Phytochemical Screening, Physicochemical analysis and Antimicrobial Activity of Bacopa monnieri (L) Extracts. Int J.Pharm.Clin.Res 2016; 8(): 12221299.

10. Akintobi OA, Nwanze JC, Ogele JO, Idowa AA, Onianwa O, Okonko IO. Antimicrobial Activity of Allium sativum (Garlic) Extract against Some Selected Pathogenic Bacteria. Nature and Science 2013; 11(): $1-5$.

11. Gupta A, Mahajan S, Sharma R. Evaluation of antimicrobial activity of Curcuma longa rhizome extract against Staphylococcus aureses and Their Biofilms. Pathogens 2015; 3(): 473-498.

12. Xu MY, Lee SY, Kang SS, Kim YS. Antitumor Activity of Jujuboside B and the Underlying Mechanism via Induction of Apoptosis and Autophagy. J.Nat.Prod. 2014; 77(): 370-376.

13. Vuong QV, Hirun S, Chuen TLK, Goldsmith CD, Murchie S, Bowyer MC, Phillips PA, Scarlett CJ et al. Antioxidant and anticancer capacity of saponin-enriched Carica papaya leaf extracts. Food Sci.Technol 2015; 50(): 169-177.

14. Ashraf MF, Aziz MA, Stanslas J, Ismailo I, Kadir MA. Assessment of Antioxidant and Cytotoxicity Activities of Saponin and Crude Extracts of Chlorophytum borivilianum. The Scientific World Journal 2013; doi.org/10.1155/2013/2013/216894.

15. Alli Smith, YR , Adanlawo, IG. In vitro and in vivo antioxidant activity of saponin extracted from the root of Garcinia kola (Bitter kola) on Alloxan-induced diabetic rats. World J. Pharm. Sci 2014; 3(): 08-26.

16. Chen Y, Miao Y, Huang L, Li J, Sun H, Zhao Y, Yang J, Zhou W et al. Antioxidant activities of saponins extracted from Radix trichosanthis: an in vivo and vitro evaluation. BMC Complementary and Alternative Medicine 2014; 14-86.

17. Subashri B, Justi Koil V, Pillai. A comparative study of antioxidant activity of Bacopa monniera (L.) Pennell using various solvent extracts and its GC-MS analysis. Int.J.Pharm.Sci 2014; 5() 396-400.

18. Chikkur BP Kumar, Kikker NM. The effect of Achyranthes aspera extracts on mild steel corrosion in industrial water medium. ISRN Corrosion 2013; http://dx.doi.org/10.1155/2013/261847

19. Nnanna Lebe A, Jehn Wisdom O, nwadiuko O. Corrosion inhibition study of aluminium alloy AA3003 in alkaline medium by Palisota hirsute extract. Int. J.Res. Rev 2014; 2(): 113-118.

20. Mahdi A, Rahem SK. Corrosion Inhibition of Reinforced steel by Thymus vulgarize (Thyme) Extract in simulated chloride contaminated concrete pore solution. Int.J.civil Eng. Technol 2014; 5(), 89-99.

21. Helen LYS, Rahim AA, Saad B, Saleh MI, Bothi Raze P. Aquilaria crassna Leaves Extracts - a Green Corrosion Inhibitor for Mild Steel in 1M HCl Medium. Int.J. Electrochem. Sci 2014; 9: 830846.

22. Onuegbu TU, Umoh ET, Ehiedu CN. Emilia sonchifolia extract as green corrosion inhibitor for mild steel in acid medium using weight loss method. J.Nat.Sci. Res. 2013; 3: 52-55.

23. Gadow HS, Fouda AS (2014) Black Tea as Green Corrosion Inhibitor for carbon Steel in $1 \mathrm{M}$ Hydrochloric Acid Solutions. Int.J.Adv.Res 2014; 2(1), 233-243.

24. Abdel Ghani AE, Dora GA, Hassan WHB, Abdallah RH, El-Salam EA (2016) New Saponins from Albizia Lebbeck (L) Benth Flowers. International J.Pharma.Science and Res 2016; 7(9): 3617-3632.

25. Wu X, Zhang J, Sun G, Yu T, Sun X, Zhang X, Zhong X, Xu X (2014) A new Dammarane-type Triterpene Saponin from the Root of Aralia elata. Rec.Nat.Prod. 2014; 8: 422-425.

26. Gulcemal D, Milena M, Napolitano A, Karayildirim T, Bedir, E, Alankus-Caliskan, O, Piacente, S et al. Oleanane glycosides from Astragalus tauricolus: Isolation and Structural elucidation based on a 
Garai Saraswati , International Journal of Ayurvedic \& Herbal Medicine 9(3) May.-June. 2019 (3492-3513) preliminary liquid chromatography-electrospay ionization tandem mass spectrometry profiling. 2013; 86: 184-194.

27. Borges RM, Valenca SS, Lopes AA, Barbi, NDS, Ribeiro da Silva AJ et al. Saponins from the roots of Chiococca alba and their in vitro anti-inflammatory activity. Phytocmem. Letts 2013; 6: 96-100.

28. Chen JY, Li PL, Tang XL, Wang SJ, Jiang YT, Shen L, Xu BM, Shao YL, Li GQ et al. Cycloartane Triterpenoids and Their Glycosides from the Rhizomes of Cimicifuga foetida. J.Nat.Prod 2014; 77: 1997-2005.

29. Williams RB, Norman VL, Goering MG, O’Neil-Johnson M, Eldridge GR, Starks CM et al. Acetylated Dammarane-Type Bisdesmosides from Combretum inflatum. J.Nat.Prod 2013; 76: 15921597.

30. Colorado J, Munoz D, Marquez D, Marquez ME, Lopez J, Thomas OP, Martinez A et al. Ulososides and Urabosides-Triterpenoid Saponins from the Caribbean Marine Sponge Ectyoplasia ferox. Molecules 2013; 18: 2598-2610.

31. Song W, Si L, Ji S, Wang H, Fang XM, Yu LY, Li RY, Liang LN, Zhou D, Ye M et al. Uralsaponins M-Y, Antiviral Triterpenoid Saponins from the Roots of Glycyrrhiza uralensis. J.Nat.Prod 2014; 77: 1632-1643.

32. Ma L, Yu AH, Sun LL, Gao W, Zhang MM, Su YL, Liu H, Ji T et al. Two New Bidesmoside Triterpenoid Saponins from the Seeds of Momordica charantia L. Molecules 2014; 19: 2238-2246.

33. Njateng GSS, Du Z, Gatsing D, Donfack ARN, Talla MF, Wabo HK, Tane P, Mouokeu RS, Luo X, Kuiate JR. et al. Antifungal properties of a new terpenoid saponin and other compounds from the stem bark of Polyscias fulva Hiern (Araliaceae). BMC Complementary and Alternative Medicine 2015; 15: 1-12. DOI 10.1186/s12906-015-0541-7

34. Sharma A, Sati SC, Sati OP, Sati MD, Kothiyal SK, Semwal DK, Mehta A et al. A New Triterpenoid Saponin and Antimicrobial Activity of Ethanolic Extract from Sepindus mukorossi Gaertn. J.Chem. 2013; 1-5. DOI org/10.1155/2013/218510

Table 1. Antimicrobial activity of P.indica leaf extracts against test microorganisms by disc diffusion method.

\section{Extracts/controls}

\section{Zone of inhibition (mm)}

B.subtilis

E.coli

S.cerevisiae

\begin{tabular}{llll}
\hline Methanol & 7.5 & No & No \\
Aqueous & 7.5 & No & No \\
DMSO & No & No & No \\
Ampicillion & 28.0 & 13.0 & No \\
Fluconazole & & & 18.5
\end{tabular}

All the extracts used at $750 \mu \mathrm{g} /$ disc. Inhibition zone diameter including disc diameter of $6 \mathrm{~mm}$. No $=$ No detectable inhibition. $(-)=$ Not tested. DMSO was used as negative control. Ampicillion $(250 \mu \mathrm{g} / \mathrm{ml})$ and Fluconazole $(10 \mathrm{mg} / \mathrm{ml})$ were used as positive controls at $3 \mu 1 /$ disc.

Table 2. MIC and MBC values of aqueous and methanolic extracts of P.indica leaf extracts against B.subtilis.

\begin{tabular}{lll}
\hline Extracts & MIC $(\mathbf{m g} / \mathbf{m L})$ & MBC $(\mathbf{m g} / \mathbf{m L})$ \\
\hline Aqueous & $3.91-7.81$ & $3.91-7.81$ \\
Methanol & $1.95-3.91$ & $1.95-3.91$ \\
\hline
\end{tabular}

Table 3. Minimum inhibitory concentration (MIC) and Minimum microbicidal concentration (MMC) of S.vulgaris extract 
Garai Saraswati , International Journal of Ayurvedic \& Herbal Medicine 9(3) May.-June. 2019 (3492-3513) Silene vulgaris extract

\begin{tabular}{|c|c|c|c|c|}
\hline & MIC $^{\mathbf{a}}$ & $\mathbf{M B C}^{\mathrm{b}}$ & MIC $^{\mathbf{a}}$ & $\mathbf{M M C}^{\mathrm{b}}$ \\
\hline Staphylococcus aureus & 25 & 50 & 0.004 & 0.004 \\
\hline Escherichia coli & 25 & 50 & 0.008 & 0.064 \\
\hline Psedomonas aeruginosa & 3 & 12.25 & 0.032 & 0.032 \\
\hline Candida albicans & 6 & 6 & - & \\
\hline Aspergillus brasiliensis & 100 & 100 & & \\
\hline
\end{tabular}

$\mathrm{MIC}^{\mathrm{a}}$ : minimum inhibitory concentration as $\mathrm{mg} / \mathrm{ml}, \mathrm{MMC}^{\mathrm{b}}:$ minimum microbicidal concentration (as $\mathrm{mg} / \mathrm{ml}),-$ : not determined

Table 4: Free radical scavenging activity of crude and total saponin extract from mother plant tubers of C.borivilianum

\begin{tabular}{llc} 
Sample & \multicolumn{2}{c}{ Antioxidant activity } \\
& $\mathrm{IC}_{50}\left(\mu \mathrm{g} \mathrm{ml}^{-1}\right)$ & $\mathrm{AEAC}(\mathrm{mg} \mathrm{AA} / 100 \mathrm{~g})^{12}$ \\
Total saponin & $440+49^{\mathrm{b}}$ & $1062+31$ \\
Crude extract & $181 \pm 34$ & $2578 \pm 111^{\mathrm{a}}$
\end{tabular}

Results are expressed as means \pm SD ( $n=3)$. For each column, values followed by different letter (a-b) are statistically significant $(\mathrm{p}<0.05)$ as determined using ANOVA

${ }^{1} \mathrm{IC}_{50}$ of $\mathrm{AA}=4.5 \mu \mathrm{g} \mathrm{mL}^{-1}$

${ }^{2} 100 \mathrm{~g}$ fresh plant materials.

Table 5: Cell viability (\%) of pancreatic cancer cell lines exposed to papaya leaf ethanol and water extracts, compared with gemcitabine

Water extract

MiaPaCa-2

ASPC-1
Ethanol extract

$95.96 \pm 5.15^{\mathrm{a}}$

$107.68 \pm 4.67^{\mathrm{cd}}$
Gemcitabine

$23.28 \pm 2.97$

$66.45 \pm 4.60$

${ }^{a} \mathrm{p}<0.0001$ of ethanol extract and gemcitabine

${ }_{\mathrm{p}}^{\mathrm{p}}=0.09$ of gemcitabine

${ }^{c} \mathrm{p}<0.0001$ of ethanol extract

${ }_{\mathrm{d}}^{\mathrm{p}}<0.0004$ of gemcitabine

${ }_{\mathrm{e}}^{\mathrm{p}}=0.0036$ of gemcitabine

Table 6: Correlation of saponins with antioxidant capacity of the extracts

\section{Antioxidant capacity $\mathbf{R}^{2}$ value}

\section{Saponins}

Total antioxidant capacity

0.7305

ABTS antioxidant capacity

0.6593

DPPH free radical scavenging capacity

$\mathrm{H}_{2} \mathrm{O}_{2}$ radical scavenging capacity

0.3275

CUPRAC

0.4830

\section{FRAP}

0.5508

CUPRAC. Cupric ion-reducing antioxidant capacity

FRAP. ferric-reducing antioxidant power 
Garai Saraswati , International Journal of Ayurvedic \& Herbal Medicine 9(3) May.-June. 2019 (3492-3513) Table 7. Triterpenoid Saponins Isolated during 2013-2016

Source Saponin, $\mathrm{mp},[\alpha]_{\mathrm{D}}$,

(1)

spectra recorded
Structure

(3)
Reference

(4)

(2)

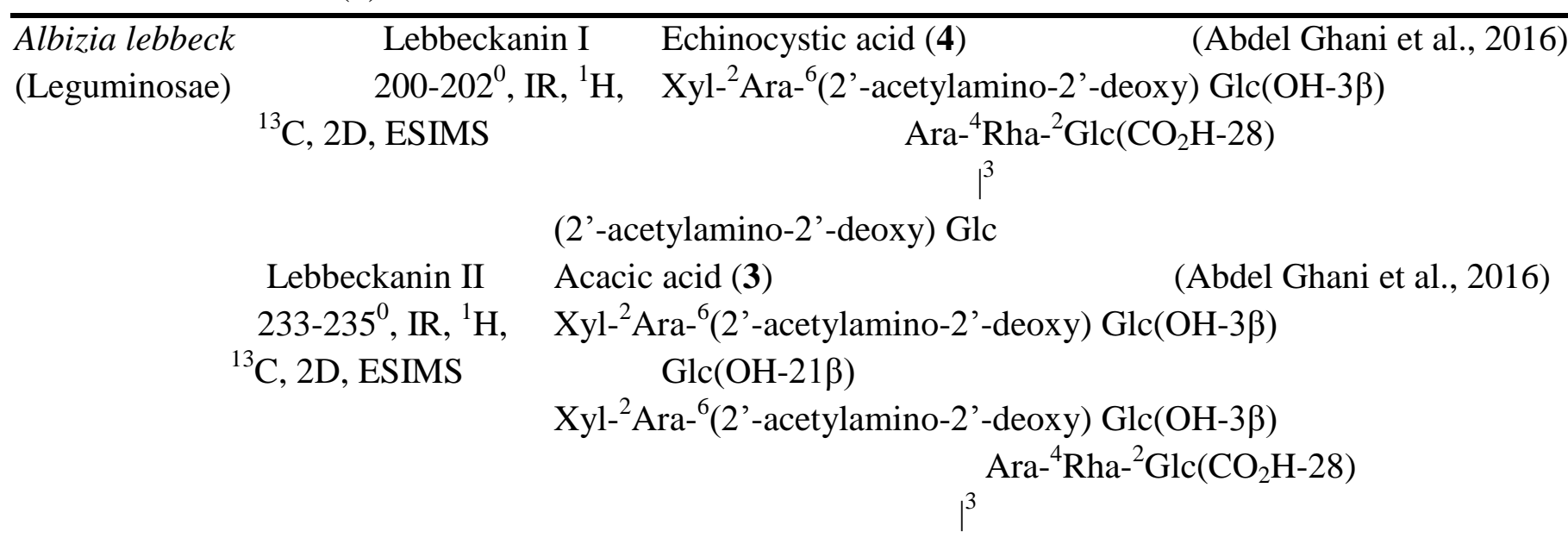

(2'-acetylamino-2'-deoxy) Glc

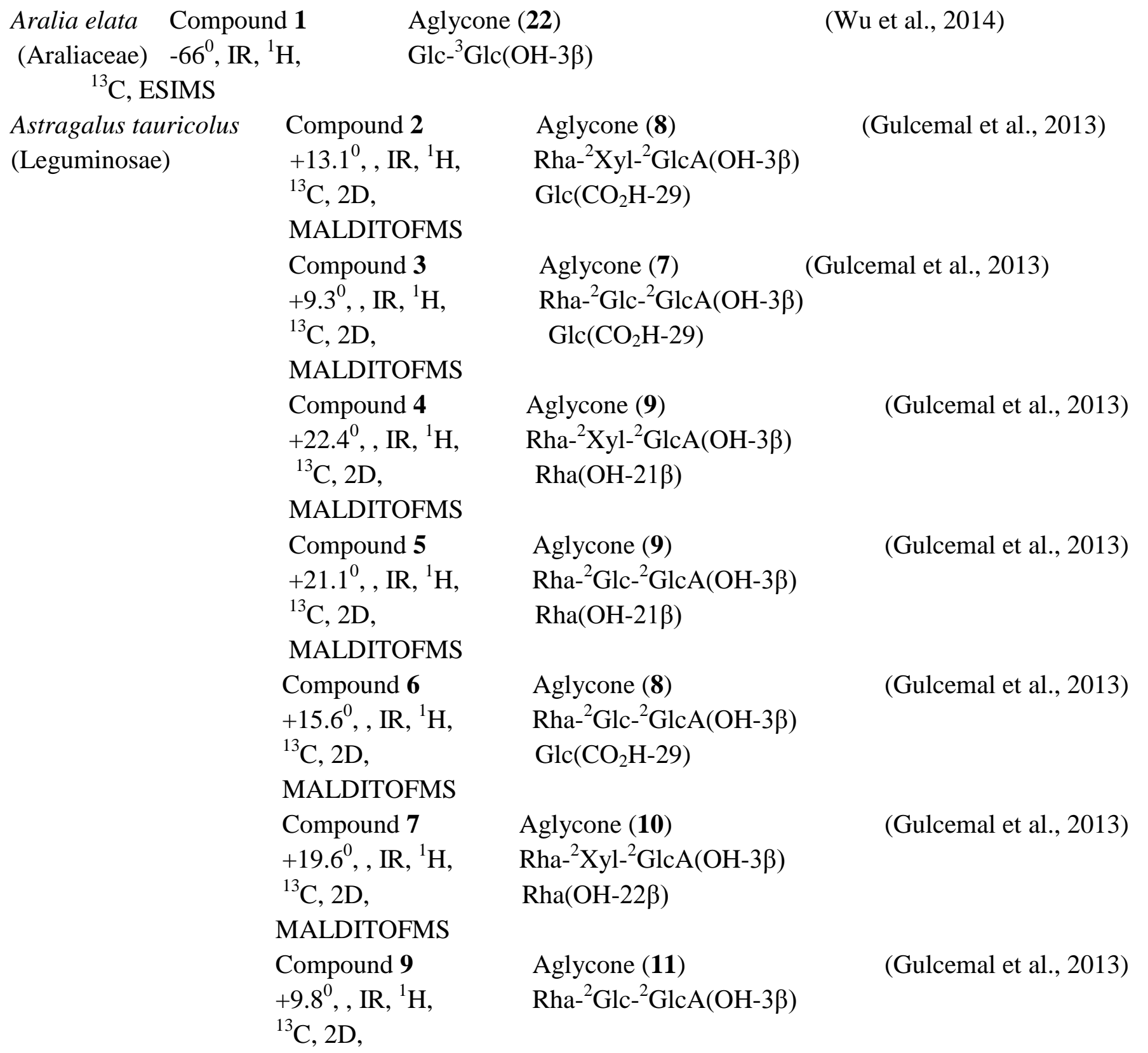


Garai Saraswati , International Journal of Ayurvedic \& Herbal Medicine 9(3) May.-June. 2019 (3492-3513) MALDITOFMS

$$
\begin{array}{ll}
\text { Compound 11 } & \text { Aglycone (12) } \\
+16.8^{0},, \text { IR },{ }^{1} \mathrm{H}, & \text { Rha- }^{2} \mathrm{Glc}-{ }^{2} \mathrm{GlcA}(\mathrm{OH}-3 \beta)
\end{array}
$$

(Gulcemal et al., 2013)

\section{MALDITOFMS}

Compound 12 Aglycone (8) (Gulcemal et al., 2013)

$$
+16.8^{0}, \text {, IR, }{ }^{1} \mathrm{H}
$$

${ }^{13} \mathrm{C} 2 \mathrm{D}$,

MALDITOFMS
Compound $14 \quad$ Aglycone (8)
$+11.5^{0},$, IR, ${ }^{1} \mathrm{H}$,
$\mathrm{Xyl}-{ }^{2} \mathrm{Glc} A(\mathrm{OH}-3 \beta)$

Glc- ${ }^{2} \mathrm{GlcA}(\mathrm{OH}-3 \beta)$

$$
{ }^{13} \mathrm{C}, 2 \mathrm{D}, \quad \mathrm{Glc}(\mathrm{OH}-29 \alpha)
$$

\section{MALDITOFMS}

Chiococca alba

Chiococasaponin III

Aglycone (13)

(Borges et al., 2013)

(Rubiaceae)

${ }^{1} \mathrm{H},{ }^{13} \mathrm{C}, 2 \mathrm{D}$

$\mathrm{GlcA}(\mathrm{OH}-3 \beta)$

Xyl- ${ }^{4}$ Rha- ${ }^{2} \mathrm{Ara}\left(\mathrm{CO}_{2} \mathrm{H}-28\right)$

Chiococasaponin IV

Aglycone (13)

$\mathrm{GlcA}(\mathrm{OH}-3 \beta)$

Rha- ${ }^{2} \mathrm{Ara}\left(\mathrm{CO}_{2} \mathrm{H}-28\right)$

Cimicifuga foetida Cimifoetidanoside A Aglycone (30)

(Chen et al., 2014)

(Ranunculaceae) $\quad+73.6, \mathrm{IR},{ }^{1} \mathrm{H},{ }^{13} \mathrm{C}, \quad \mathrm{Xyl}(\mathrm{OH}-3 \beta)$

2D, ESIMS

Cimifoetidanoside B Aglycone (31)

(Chen et al., 2014)

-29.7, IR, ${ }^{1} \mathrm{H},{ }^{13} \mathrm{C}, \quad \mathrm{Xyl}(\mathrm{OH}-3 \beta)$

2D, ESIMS

Cimifoetidanoside C Aglycone (32)

(Chen et al., 2014)

+95.2, IR, ${ }^{1} \mathrm{H},{ }^{13} \mathrm{C}, \quad \mathrm{Xyl}(\mathrm{OH}-3 \beta)$

2D, ESIMS

Cimifoetidanoside D Aglycone (37)

(Chen et al., 2014)

-24.1, IR, ${ }^{1} \mathrm{H},{ }^{13} \mathrm{C}, \quad \mathrm{Xyl}(\mathrm{OH}-3 \beta)$

2D, ESIMS

Cimifoetidanoside E Aglycone (33)

(Chen et al., 2014)

-51.4, IR, ${ }^{1} \mathrm{H},{ }^{13} \mathrm{C}, \quad \mathrm{Xyl}(\mathrm{OH}-3 \beta)$

2D, ESIMS

Cimifoetidanoside F Aglycone (34)

(Chen et al., 2014)

$-44.0, \mathrm{IR},{ }^{1} \mathrm{H},{ }^{13} \mathrm{C}, \quad \mathrm{Xyl}(\mathrm{OH}-3 \beta)$

2D, ESIMS

Cimifoetidanoside $\mathrm{G}$ Aglycone (35)

(Chen et al., 2014)

$-60.2, \mathrm{IR},{ }^{1} \mathrm{H},{ }^{13} \mathrm{C}, \quad \mathrm{Xyl}(\mathrm{OH}-3 \beta)$

2D, ESIMS

Cimifoetidanoside $\mathrm{H}$ Aglycone (36)

(Chen et al., 2014)

-27.0, IR, ${ }^{1} \mathrm{H},{ }^{13} \mathrm{C}, \quad \mathrm{Xyl}(\mathrm{OH}-3 \beta)$

2D, ESIMS

Combretum inflatum Combretaside A Aglycone (23)

(Combretaceae)

${ }^{1} \mathrm{H},{ }^{13} \mathrm{C}$, ESIMS

(Williams et al., 2013)

$\operatorname{Fuc}(\mathrm{OH}-2 \alpha)$ 
Garai Saraswati , International Journal of Ayurvedic \& Herbal Medicine 9(3) May.-June. 2019 (3492-3513) Fuc $(\mathrm{OH}-11 \alpha)$

Combretaside B

${ }^{1} \mathrm{H},{ }^{13} \mathrm{C}$, ESIMS

Aglycone (23)

(Williams et al., 2013)

$\operatorname{Fuc}(\mathrm{OH}-11 \alpha)$

Combretaside $\mathrm{C}$

${ }^{1} \mathrm{H},{ }^{13} \mathrm{C}$, ESIMS

Quin $(\mathrm{OH}-2 \alpha)$

Fuc $(\mathrm{OH}-11 \alpha)$

Combretaside D

${ }^{1} \mathrm{H},{ }^{13} \mathrm{C}$, ESIMS

Fuc $(\mathrm{OH}-11 \alpha)$

Combretaside E

${ }^{1} \mathrm{H},{ }^{13} \mathrm{C}$, ESIMS

Aglycone (24)

(Williams et al., 2013)

$\mathrm{Fuc}(\mathrm{OH}-2 \alpha)$

Aglycone (24)

(Williams et al., 2013)

Quin $(\mathrm{OH}-2 \alpha)$

Aglycone (25)

(Williams et al., 2013)

$\mathrm{Fuc}(\mathrm{OH}-11 \alpha)$

Combretaside $\mathrm{F}$

${ }^{1} \mathrm{H},{ }^{13} \mathrm{C}$, ESIMS

Aglycone (25)

(Williams et al., 2013)

$\operatorname{Ara}(\mathrm{OH}-11 \alpha)$

Combretaside $\mathrm{G}$

Quin $(\mathrm{OH}-2 \alpha)$

${ }^{1} \mathrm{H},{ }^{13} \mathrm{C}$, ESIMS

Aglycone (26)

(Williams et al., 2013)

Fuc $(\mathrm{OH}-11 \alpha)$

Ectyoplasia ferox Uraboside A

$\operatorname{Fuc}(\mathrm{OH}-2 \alpha)$

Fuc $(\mathrm{OH}-2 \alpha)$

(Raspailiidae) $\quad-33.0, \mathrm{IR},{ }^{1} \mathrm{H}$,

Aglycone (27)

(Colardo et al., 2013)

${ }^{13} \mathrm{C}, 2 \mathrm{D}, \mathrm{ESIMS}$

Uraboside B

-130, IR, ${ }^{1} \mathrm{H}$,

${ }^{13} \mathrm{C}, 2 \mathrm{D}, \mathrm{ESIMS}$

Ulososide $\mathrm{F}$

Aglycone (28)

Ara- $-{ }^{2} \mathrm{Gal}-{ }^{3} \mathrm{Gal}(\mathrm{OH}-3 \beta)$

(Colardo et al. 2013)

$-4.0, \mathrm{IR},{ }^{1} \mathrm{H}$,

${ }^{13} \mathrm{C}, 2 \mathrm{D}$, ESIMS

Glycyrrhiza

Uralsaponin $\mathrm{M}$

Gal- ${ }^{2} \mathrm{Glc}(\mathrm{OH}-3 \beta)$

(Colardo et al., 2013)

uralensis +204, UV, IR, ${ }^{1} \mathrm{H}$,

Aglycone (14)

(Song et al., 2014)

(Fabaceae)

${ }^{13} \mathrm{C}, 2 \mathrm{D}$, ESIMS

Uralsaponin $\mathrm{N}$

Aglycone (29)

(Colardo et al., 2013)

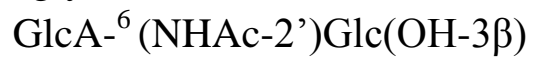

+193, UV, IR, ${ }^{1} \mathrm{H}$

${ }^{13} \mathrm{C}, 2 \mathrm{D}$, ESIMS

Uralsaponin $\mathrm{O}$

$+188, \mathrm{UV}, \mathrm{IR},{ }^{1} \mathrm{H}$

${ }^{13} \mathrm{C}, 2 \mathrm{D}$, ESIMS

Uralsaponin $\mathrm{P}$

+190, UV, IR, ${ }^{1} \mathrm{H}$

${ }^{13} \mathrm{C}, 2 \mathrm{D}$, ESIMS

Uralsaponin Q

Aglycone (19)

(Song et al., 2014)

+190, UV, IR, ${ }^{\mathrm{i}} \mathrm{H}$,

Aglycone (15)

Gal- ${ }^{2} \mathrm{GlcA}(\mathrm{OH}-3 \beta)$

Gal- ${ }^{2} \mathrm{GlcA}(\mathrm{OH}-3 \beta)$

Aglycone (18)

(Song et al., 2014)

Gal- ${ }^{2} \mathrm{Glc} A(\mathrm{OH}-3 \beta)$

Aglycone (19)

(Song et al., 2014)

${ }^{13} \mathrm{C}, 2 \mathrm{D}$, ESIMS

Uralsaponin $\mathrm{R}$

Gal- ${ }^{2} \mathrm{GlcA}(\mathrm{OH}-3 \beta)$

(Song et al., 2014)

+189, UV, IR, ${ }^{1} \mathrm{H}$,

GlcA- ${ }^{2} \mathrm{Xyl}-{ }^{2} \mathrm{Rha}(\mathrm{OH}-3 \beta)$

Aglycone (19)

(Song et al., 2014)

${ }^{13} \mathrm{C}, 2 \mathrm{D}, \mathrm{ESIMS}$

GalA- ${ }^{2}$ Glc- ${ }^{2}$ Rha(OH-3 $\beta$ ) 
Garai Saraswati , International Journal of Ayurvedic \& Herbal Medicine 9(3) May.-June. 2019 (3492-3513)

Uralsaponin $\mathrm{S}$

Aglycone (19)

(Song et al., 2014)

$+189, \mathrm{UV}, \mathrm{IR},{ }^{1} \mathrm{H}, \quad$ GlcA- ${ }^{2} \mathrm{Glc}-{ }^{2} \mathrm{Rha}(\mathrm{OH}-3 \beta)$

${ }^{13} \mathrm{C}, 2 \mathrm{D}$, ESIMS

Uralsaponin $\mathrm{T}$

Aglycone (20)

(Song et al., 2014)

+199, UV, IR, ${ }^{1} \mathrm{H}, \quad$ GlcA $-{ }^{2} \mathrm{GlcA}(\mathrm{OH}-3 \beta)$

${ }^{13} \mathrm{C}, 2 \mathrm{D}, \mathrm{ESIMS}$

Uralsaponin U

Aglycone (16)

(Song et al., 2014)

+192, UV, IR, ${ }^{1} \mathrm{H}$

${ }^{13} \mathrm{C}, 2 \mathrm{D}, \mathrm{ESIMS}$

Uralsaponin $\mathrm{V}$

$\mathrm{GlcA}-{ }^{2} \mathrm{GlcA}(\mathrm{OH}-3 \beta)$

Aglycone (38)

(Song et al., 2014)

+187, UV, IR, ${ }^{1} \mathrm{H}$

${ }^{13} \mathrm{C}, 2 \mathrm{D}$, ESIMS

Uralsaponin W

$+170, \mathrm{UV}, \mathrm{IR},{ }^{1} \mathrm{H}$

${ }^{13} \mathrm{C}, 2 \mathrm{D}$, ESIMS

Uralsaponin X

+193, UV, IR, ${ }^{1} \mathrm{H}$,

${ }^{13} \mathrm{C}, 2 \mathrm{D}, \mathrm{ESIMS}$

Uralsaponin $\mathrm{Y}$

GlcA- ${ }^{2} \mathrm{GlcA}(\mathrm{OH}-3 \beta)$

Aglycone (17)

(Song et al., 2014)

GlcA- ${ }^{2} \mathrm{Glc} A(\mathrm{OH}-3 \beta)$

Aglycone (14)

(Song et al., 2014)

GlcA- ${ }^{2}$ GlcA- $-{ }^{2}$ Rha(OH-3 $\left.\beta\right)$

Aglycone (18)

(Song et al., 2014)

$+185, \mathrm{UV}, \mathrm{IR},{ }^{1} \mathrm{H}, \quad$ GlcA- $-{ }^{2} \mathrm{GlcA}-{ }^{2} \mathrm{Rh}$ (OH-3 $\left.\beta\right)$

${ }^{13} \mathrm{C}, 2 \mathrm{D}, \mathrm{ESIMS}$

Momordica

Compound $\mathrm{C}_{1}$

Gypsogenin (6)

(Ma et al., 2014)

charantia

${ }^{1} \mathrm{H},{ }^{13} \mathrm{C}, 2 \mathrm{D}$, ESIMS $\quad \mathrm{Glc}-{ }^{2} \mathrm{GlcA}(\mathrm{OH}-3 \beta)$

(Cucurbitaceae)

Rha- ${ }^{3} \mathrm{Fuc}\left(\mathrm{CO}_{2} \mathrm{H}-28\right)$

Xyl- ${ }^{3}$ Xyl- ${ }^{4}$ Rha

Compound $\mathrm{C}_{2} \quad$ Gypsogenin (6)

(Ma et al., 2014)

${ }^{1} \mathrm{H},{ }^{13} \mathrm{C}, 2 \mathrm{D}$, ESIMS Glc- ${ }^{2} \mathrm{GlcA}(\mathrm{OH}-3 \beta)$

Rha- ${ }^{3} \mathrm{Fuc}\left(\mathrm{CO}_{2} \mathrm{H}-28\right)$

Rha- ${ }^{4} \mathrm{Xyl}$

Momordica

Compound $\mathrm{C}_{1} \quad$ Gypsogenin (6)

(Ma et al., 2014)

charantia

${ }^{1} \mathrm{H},{ }^{13} \mathrm{C}, 2 \mathrm{D}$, ESIMS Glc- ${ }^{2} \mathrm{GlcA}(\mathrm{OH}-3 \beta)$

(Cucurbitaceae) Rha- ${ }^{3} \mathrm{Fuc}\left(\mathrm{CO}_{2} \mathrm{H}-28\right)$

$$
\text { Xyl- }{ }^{3} \mathrm{Xyl}-{ }^{4} \mathrm{Rha}
$$

Compound $\mathrm{C}_{2} \quad$ Gypsogenin (6)

(Ma et al., 2014)

${ }^{1} \mathrm{H},{ }^{13} \mathrm{C}, 2 \mathrm{D}$, ESIMS Glc- ${ }^{2} \mathrm{GlcA}(\mathrm{OH}-3 \beta)$

Rha- ${ }^{3} \mathrm{Fuc}\left(\mathrm{CO}_{2} \mathrm{H}-28\right)$

Rha- ${ }^{4} \mathrm{Xyl}$

Polyscias fulva

Compound 11

Hederagenin (5)

(Njateng et al., 2015)

(Araliaceae)

213-215, -38.9, IR, $\quad$ Rha $^{2} \mathrm{Ara}(\mathrm{OH}-3 \beta)$

(OAc-4')Rha- ${ }^{4}$ Glc- ${ }^{6} \mathrm{Glc}\left(\mathrm{CO}_{2} \mathrm{H}-28\right)$

Sapindus

Compound 1

Hederagenin (5)

(Sharma et al., 2013) 
Garai Saraswati , International Journal of Ayurvedic \& Herbal Medicine 9(3) May.-June. 2019 (3492-3513)

Mukorossi

(Sapindaceae)

Spergula fallax
${ }^{1} \mathrm{H},{ }^{13} \mathrm{C}$, ESIMS

$\mathrm{Rha}\left(\mathrm{CO}_{2} \mathrm{H}-28\right)$

Compound 1 $-36.0, \mathrm{IR},{ }^{1} \mathrm{H}$,

${ }^{13} \mathrm{C}$, MALDITOFMS

Compound 2

$+20.7, \mathrm{IR},{ }^{1} \mathrm{H}$,

Aglycone (21)

$\mathrm{Ara}(\mathrm{OH}-16 \alpha)$

${ }^{13} \mathrm{C}$, MALDITOFMS

Compound 3

$+32.0, \mathrm{IR},{ }^{1} \mathrm{H}$,

${ }^{13} \mathrm{C}$, MALDITOFMS

Compound 4

$+5.23, \mathrm{IR},{ }^{1} \mathrm{H}$,

Aglycone (21)

(OAc-4')Ara(OH-16 $\alpha$ )

${ }^{13} \mathrm{C}$, MALDITOFMS Glc(OH-20 $\left.\beta\right)$
(OAc-3')Ara ${ }^{2} \mathrm{Xyl}(\mathrm{OH}-3 \beta)$

(1)

(Hamed et al., 2014)
(Hamed et al., 2014)

(Hamed et al., 2014)

(Hamed et al., 2014)

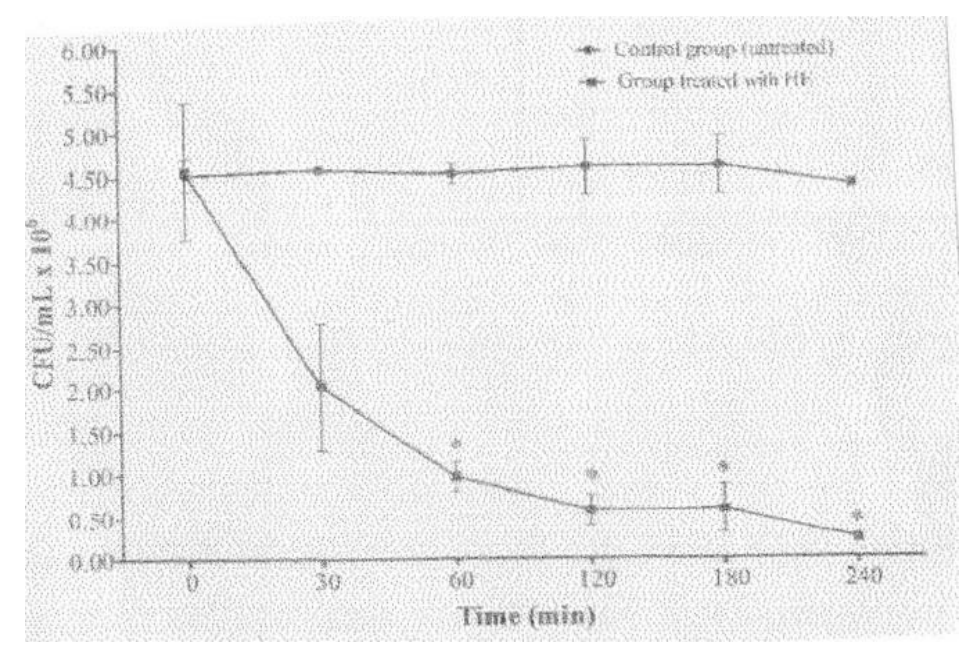

Figure 1. Time kill profile of C.albicans ATCC 90028 during exposition to HE $(1560 \mu \mathrm{g} / \mathrm{mL})$. CFU/mL: Colony forming unit per mililitre * Indicates significant reduction in CFU 
Garai Saraswati , International Journal of Ayurvedic \& Herbal Medicine 9(3) May.-June. 2019 (3492-3513)

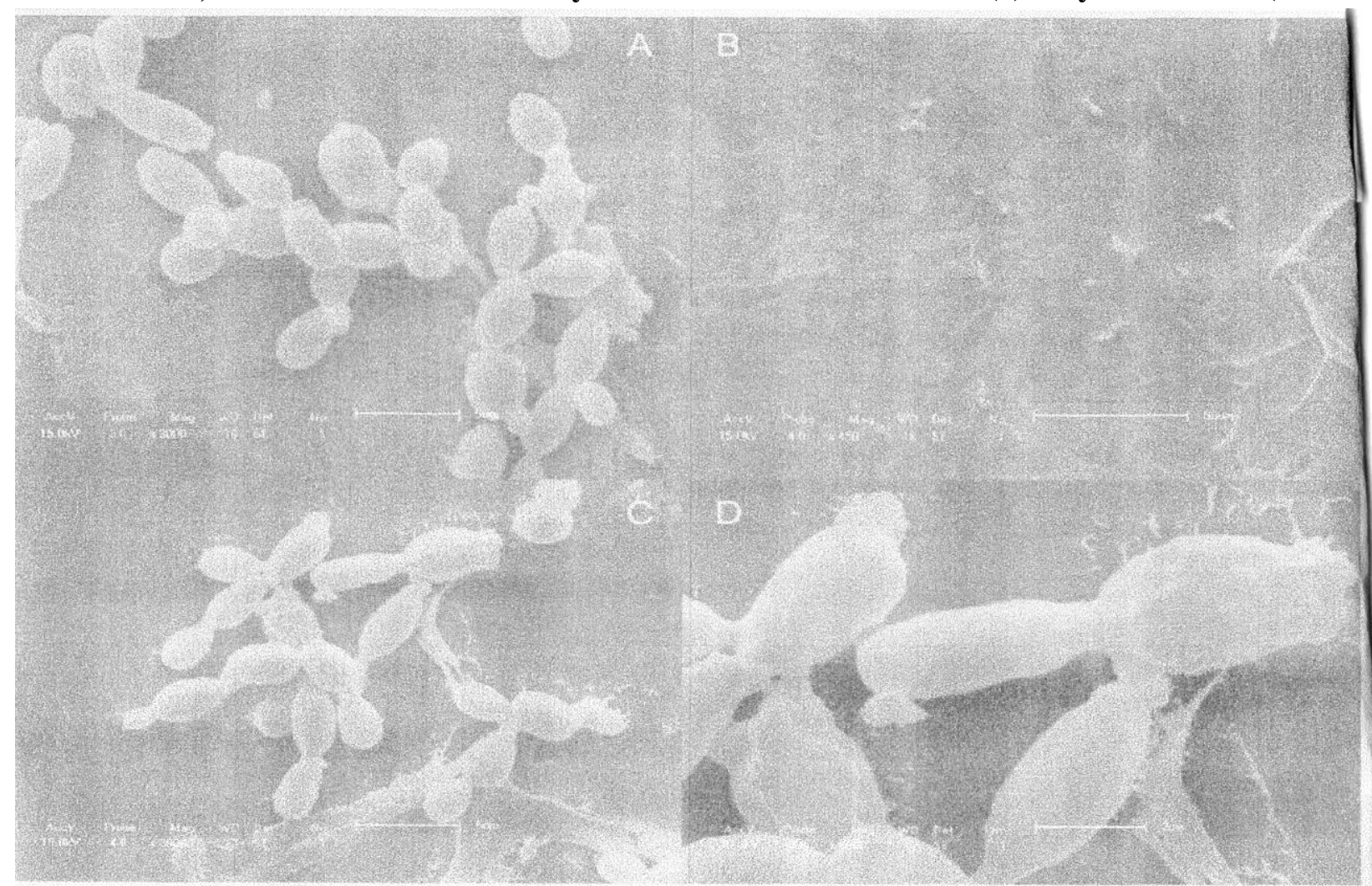

Figure 2. SEM micrographs of the untreated $(\mathbf{A}), 30 \mathrm{~min}(\mathbf{B})$ and $120 \mathrm{~min}(\mathbf{C}, \mathbf{D}) \mathrm{HE}(1560 \mu \mathrm{g} / \mathrm{mL})$ treated C.albicans ATCC 90028 cells.

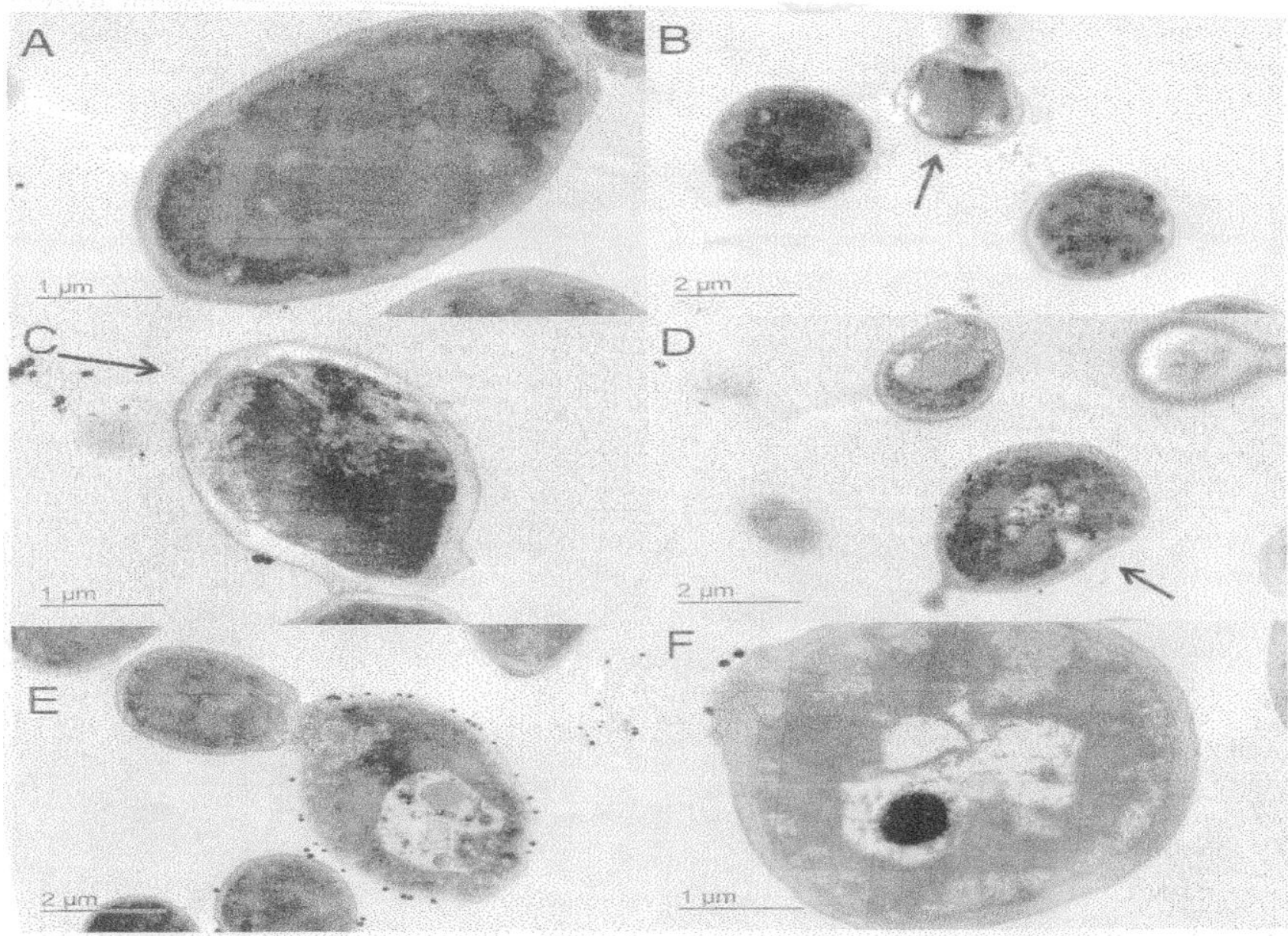

Figure 3. TEM micrographs of the untreated (A), $30 \mathrm{~min}(\mathbf{B}$ and $\mathbf{C})$ and $120 \mathrm{~min}(\mathbf{D}-\mathbf{F})$ treated cells of C.albicans ATCC 90028 with HE with concentration of $1560 \mu \mathrm{g} / \mathrm{mL}$. 
Garai Saraswati , International Journal of Ayurvedic \& Herbal Medicine 9(3) May.-June. 2019 (3492-3513)

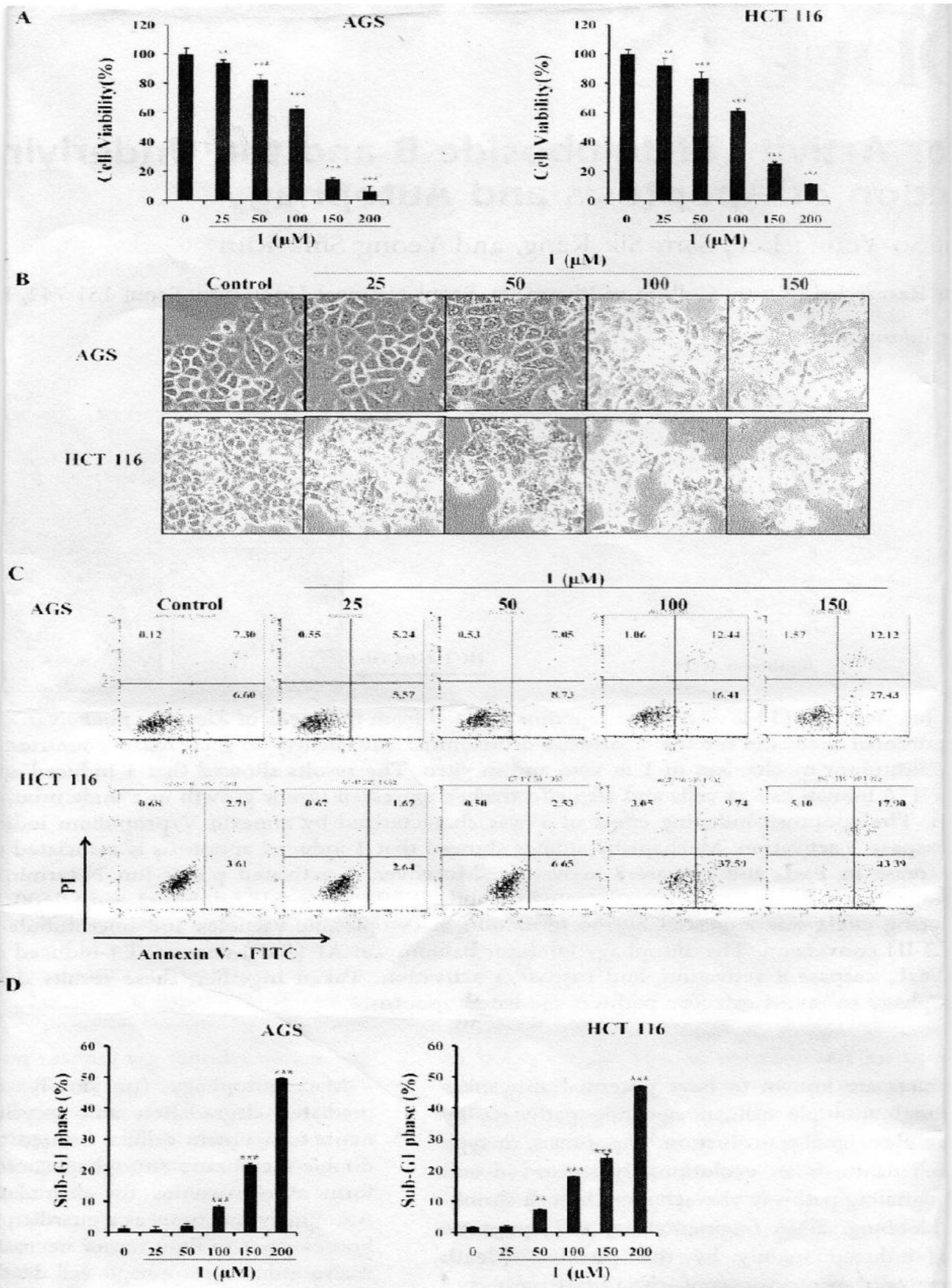

Figure 4. Jujuboside B induces apoptosis in AGS and HCT 116 cells. Cells were treated with the indicated concentrations of Jujboside B for $24 \mathrm{~h}$, and (A) the cell viabilities were determined using the MTT assay. The values are expressed as the means \pm SD of three individual experiments $\left(^{*} \mathrm{p}<0.05 ;{ }^{* *} \mathrm{p}<0.01\right.$; ${ }^{* * *} \mathrm{p}<0.001$ vs the untreated control group). (B) Morphological changes were visualized at $100 \mathrm{X}$ magnification under CKX41 microscopy. (C) Flow cytometry analysis of annexin V/PI double staining was performed to measure the apoptotic and necrotic cells. A representative result from three separate experiments is shown. (D) The ratio of sub-G1 phase was measured by Flow cytometry. The values are expressed as the means \pm SD of three individual experiments $\left({ }^{*} \mathrm{p}<0.05 ;{ }^{* *} \mathrm{p}<0.01 ;{ }^{* * *} \mathrm{p}<0.001\right.$ vs the untreated control group). 
Garai Saraswati , International Journal of Ayurvedic \& Herbal Medicine 9(3) May.-June. 2019 (3492-3513)
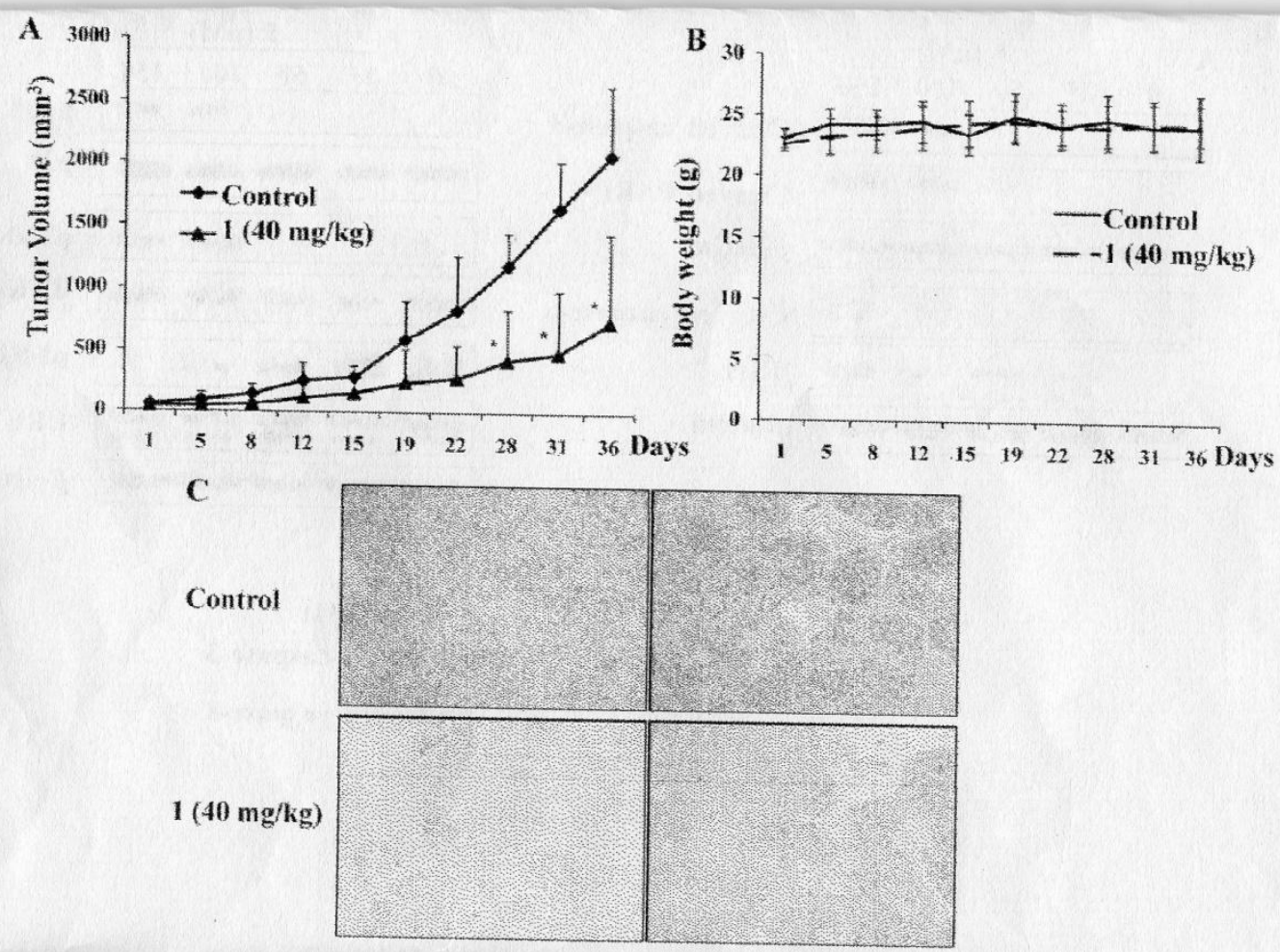

Figure 5. Antitumor effect of Jujuboside B in a tumor xenograft model beating HCT 116 cells were implanted subcutaneously into the right flank of each mouse. When the tumor size reached $60 \mathrm{~mm}^{3}$, the mice were treated intraperitoneally with Jujuboside B $(40 \mathrm{mg} / \mathrm{kg})$ three times a week for 5 weeks. (A) The tumor sizes were measured twice a week $\left({ }^{*} \mathrm{p}<0.05\right.$ vs the untreated ontrol group). (B) The body weight of each mouse was monitored for toxicity. (C) Immunohistochemical analysis of the cell proliferation marker $\mathrm{K}_{\mathrm{i}}-67$ from the tumor tissues, visualized at 200x magnification under CKX41 fluorescence microscopy. A representative result from two different tumor tissues is shown.

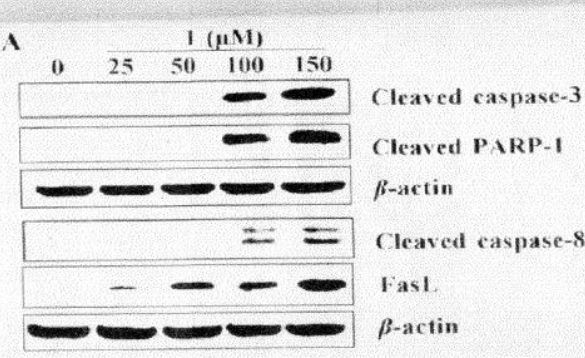

B
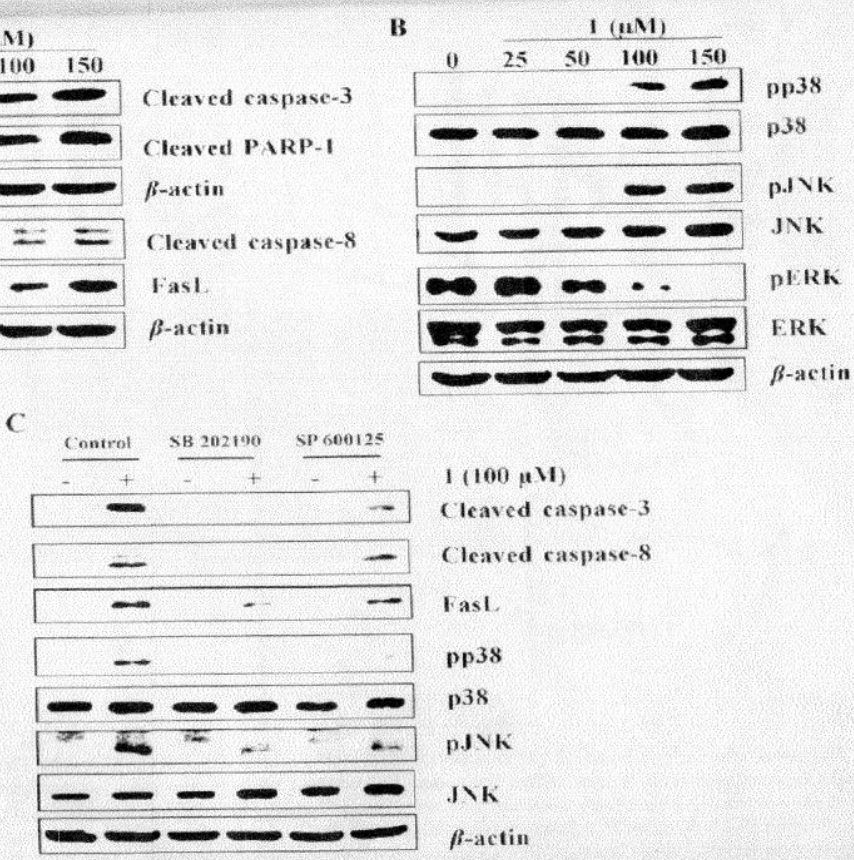

Figure 6. Jujuboside B activates p38/JNK to promote extrinsic pathway-mediated apoptosis through FasL regulation in AGS cells. (A) Cells were treated with the indicated concentrations of Jujuboside B for 24h, and western blotting was performed for cleaved caspase-3, cleaved caspase-8, cleaved PARP-1, Fasl. $\beta$ - 
Garai Saraswati , International Journal of Ayurvedic \& Herbal Medicine 9(3) May.-June. 2019 (3492-3513) Actin was used as a loading control (B) Cells were treated with the indicated concentrations of Jujuboside B for $24 \mathrm{~h}$, and Western blotting was performed for pp38, p38, pJNK, JNK, pERK, and ERK, $\beta$-Actin was used as a loading control (C) Cells were pretreated with 5 $\mu$ M SB202190 and $5 \mu$ M SP600125 for 30 min, and then $100 \mu \mathrm{M}$ for $24 \mathrm{~h}$. Western blotting was performed for cleaved caspase-3, cleaved caspase-8, FasL, pp38, p38, pJNK and JNK. $\beta$-Actin was used as a loading control. A representative result from three separate experiments is shown.

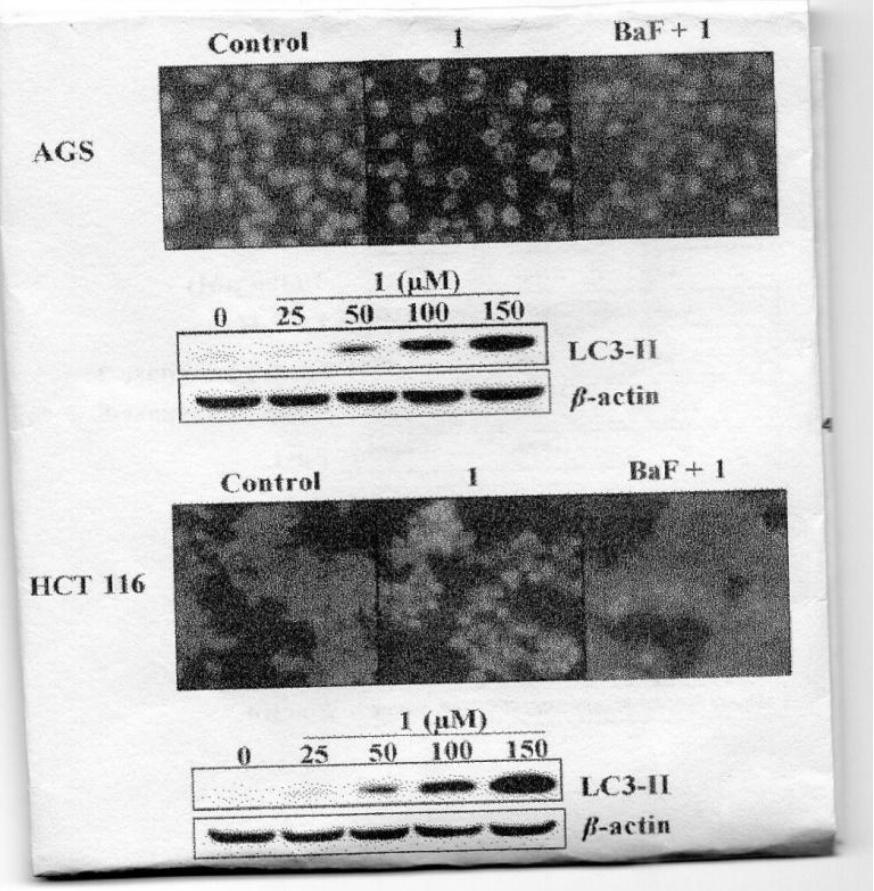

Figure 7. Jujuboside B induces autophagy in AGS and HCT 116 cells. Cells were treated with $50 \mu \mathrm{M}$ Jujuboside $\mathrm{B}$ in the presence or absence of $2.5 \mathrm{nM}$ bafilomycin $\mathrm{A} 1 \mathrm{BaF}$ ) for $24 \mathrm{~h}$, stained by acridine orange (AO), and visualized at 200x magnification under CKX41 fluorescence microscopy. Cells were treated with the indicated concentrations of Jujuboside B for $24 \mathrm{~h}$, and Western blotting was performed for LC3-II. $\beta$-Actin was used as a loading control. A representative result from three separate experiments is shown.

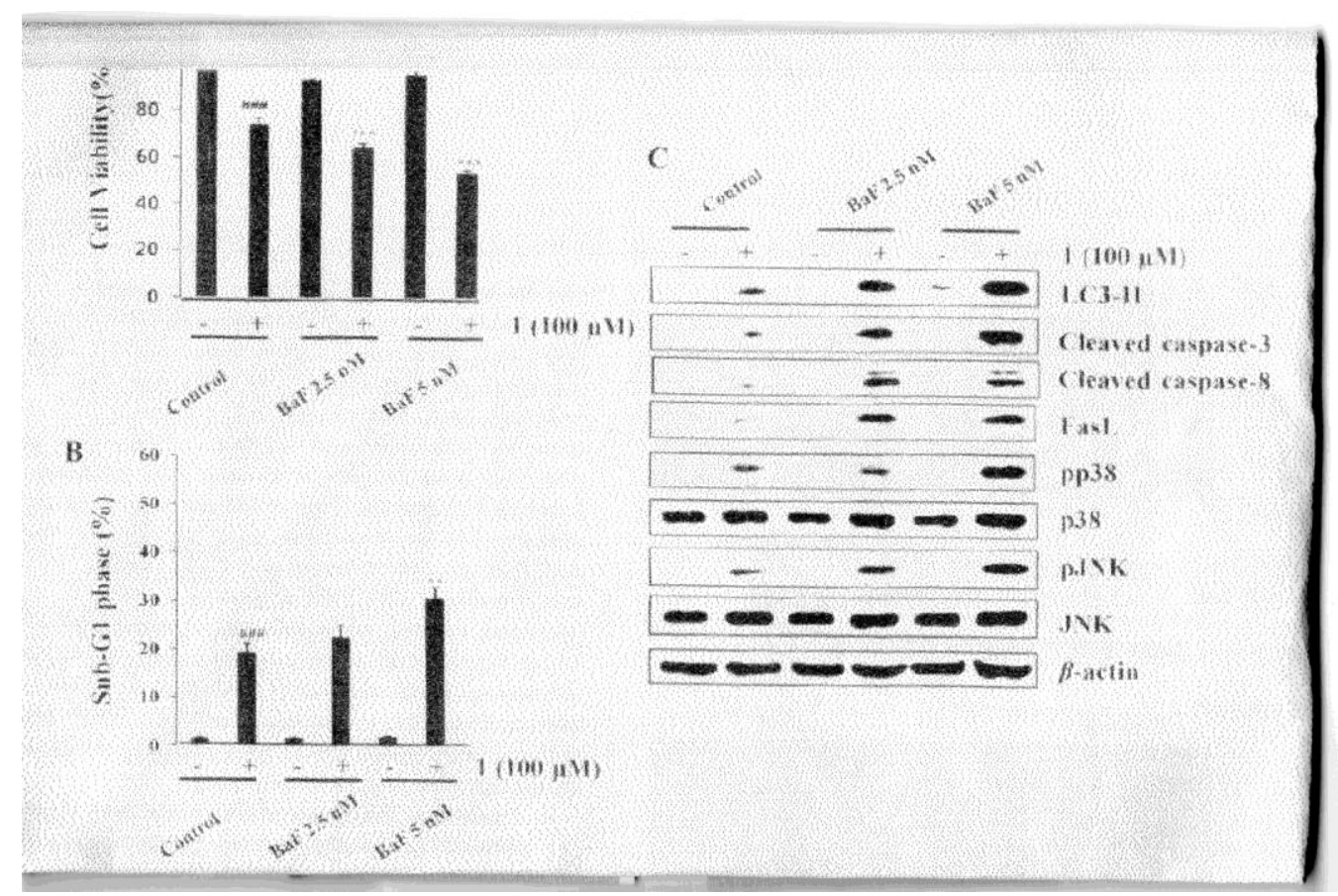

Figure 8. Jujuboside B induces protective autophagy to retard apoptosis in AGS cells were pretreated with $\mathrm{BaF}$ for $30 \mathrm{~min}$, then $100 \mu \mathrm{M}$ Jujuboside B was added for $24 \mathrm{~h}$ and (A) the cell viabilities were determined 
Garai Saraswati , International Journal of Ayurvedic \& Herbal Medicine 9(3) May.-June. 2019 (3492-3513) using the MTT assay. The values are expressed as the means \pm SD of three individual experiments $\left({ }^{* * *} \mathrm{p}<\right.$ 0.001 vs the untreated control group, ${ }^{* * *} \mathrm{p}<0.001$ vs the Jujuboside B treated group). (B) The ratio of subG1 phase was measured by flow cytometry. The values are expressed as the means \pm SD of three individual experiments $\left({ }^{* * *} \mathrm{p}<0.001\right.$ vs the untreated control group, ${ }^{* *} \mathrm{p}<0.001$ vs the Jujuboside B treated group). (C) Western blotting was performed for cleaved caspase-3, cleaved caspase-8, FasL, pp38, p38, pJNK and JNK. $\beta$-Actin was used as a loading control. A representative result from three separate experiments is shown. 